\title{
Summary of Physical Properties Measured at Several Boreholes Penetrating through the Chelungpu Fault in Central Taiwan
}

\author{
Jeen-Hwa Wang* \\ Institute of Earth Sciences, Academia Sinica, Taipei 115, Taiwan, ROC
}

Received 23 March 2009, accepted 1 September 2009

\begin{abstract}
On 20 September 1999, the $\mathrm{M}_{\mathrm{s}}$ 7.6 Chi-Chi earthquake ruptured the Chelungpu fault in central Taiwan. After the earthquake, several boreholes of different depths were drilled. Those boreholes penetrated the fault plane. The physical (mechanical, thermal, hydraulic, electric, and magnetic) parameters were measured either on the core samples or through well-loggings. Results are significant for studies of the Chelungpu fault. However, the measured results are published in different articles and reports. It is not convenient for the earth scientists to take advantage of those results. Hence, those results are compiled and described in this paper. In addition, the correlations among a few parameters are also reported.
\end{abstract}

Key words: Chelungpu fault, Borehole, Well-logging, Physical parameters

Citation: Wang, J. H., 2010: Summary of physical properties measured at several boreholes penetrating through the Chelungpu fault in central Taiwan. Terr. Atmos. Ocean. Sci., 21, 655-673, doi: 10.3319/TAO.2009.09.01.01(T)

\section{INTRODUCTION}

On 20 September 1999, the $\mathrm{M}_{\mathrm{s}}$ 7.6 Chi-Chi earthquake ruptured the Chelungpu fault, which is a $\sim 100-\mathrm{km}-$ long and east-dipping thrust fault, with a dip angle of $\sim 30^{\circ}$, in central Taiwan (Ma et al. 1999; Shin and Teng 2001). The epicenter, fault trace, and the fault plane are displayed in Fig. 1. Mori et al. (2002) noted that fault drillings could resolve some significant seismological issues. After the earthquake, several boreholes of different depths were drilled. Through a joint Taiwan-Japan cooperative project, in 2001 two shallow boreholes near the northern and southern segments of the Chelungpu fault were drilled (cf. Huang et al. 2002; Tanaka et al. 2002). The locations are depicted by "Northern Hole" and "Southern Hole" in Fig. 1. The northern hole, which was located at Fengyuan, consisted of two linked holes: BH-1 from 0 to $293.4 \mathrm{~m}$ and $\mathrm{BH}-1 \mathrm{~A}$ from 208 to $455.35 \mathrm{~m}$. There was an overlap of $85.4 \mathrm{~m}$ between the two holes. The depth of the southern hole was $211.9 \mathrm{~m}$. The distances from the northern and southern drilling sites to the fault trace are 500 and $250 \mathrm{~m}$, respectively.

Huang et al. (2002) observed that the northern hole consists of three major stratigraphic units: Yutenping sand-

\footnotetext{
* Corresponding author

E-mail:jhwang@earth.sinica.edu.tw
}

stone, Chinshui shale, and terrace deposits; while the southern hole has three major stratigraphic units: the Toukoshan Formation, Chinshui shale, and terrace deposits. They found that the two holes encountered the fault plane of the Chi-Chi earthquake and also recognized two possible fracture zones in the northern and southern boreholes at 225 - 330 and 177 - $180 \mathrm{~m}$, respectively. Detailed description of cores can be found in Huang et al. (2002) and Tanaka et al. (2002). The main results observed by several authors (Otsuki et al. 2001; Huang et al. 2002; Tanaka et al. 2002; and Tanikawa et al. 2004) are (1) for the northern borehole: (a) a random fabric breccia distribution of several tens of centimeters thick; (b) the presence of a fault gouge of $0.5-2 \mathrm{~cm}$ thick; (c) intrusion of soft clay into layers of fault breccia; and (2) for the southern site, (a) the existence of foliated fault breccia with ultracataclasites and pseudotachylites and (b) a lack of any injection structure. Geophysical well-loggings were also made at the two shallow holes (see Tanaka et al. 2002).

To investigate the physical and chemical properties of the fault zone, the Taiwan Chelungpu-fault Drilling Project (TCDP) was launched in 2004 (Song et al. 2007a). Two deep holes (denoted as Hole-A and Hole-B, respectively, hereafter) cutting through the fault plane were drilled in 2005 (Fig. 1). The two deep holes are $40 \mathrm{~m}$ apart: Hole-A reached to a depth of $2003.26 \mathrm{~m}$ and Hole-B reached to a depth of 


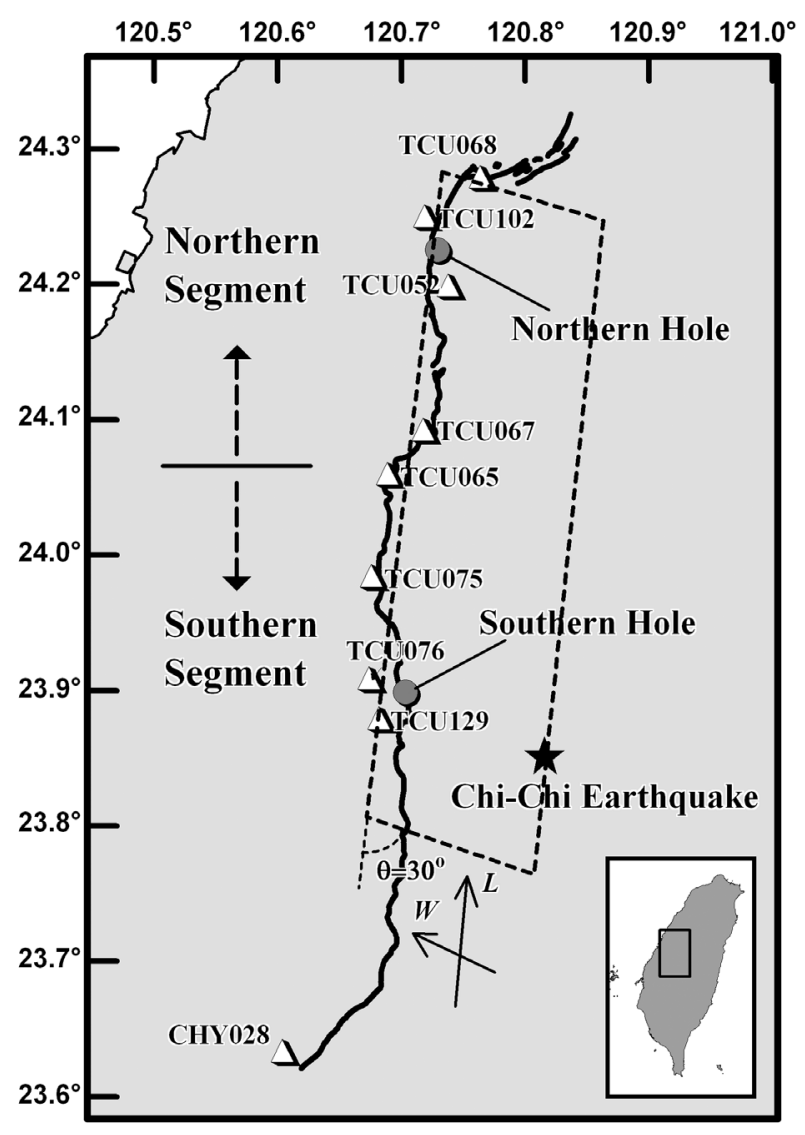

Fig. 1. A figure to show the epicenter (in a solid star), the Chelungpu fault (in a solid line), the fault plane (in the range bounded by four dashed lines), the nine near-fault seismic station sites (in open triangles), and the borehole sites (in solid circles). The northern and southern segments of the fault are separated at a locality near Station TCU065.

$1352.60 \mathrm{~m}$. Figure 2 shows the structural profile across Hole-A. Lin et al. (2007) observed that the lithostratigraphy for the Hole-A are: (1) the lower Plio-Pleistocene Cholan Formation from 0 - 1013 m; (2) Pliocene Chinshui Shale from 1013 - 1300 m; (3) the Miocene Kueichulin Formation in 1300 - $1707 \mathrm{~m}$; and (4) the repeated Cholan Formation in $1707-2003 \mathrm{~m}$.

From the core samples of Hole-A, Hung et al. (2007) and Yeh et al. (2007) identified a total of 10 - 12 faults zones. The shallowest fault zone at depths $1110.37-1111.29 \mathrm{~m}$ is considered to be associated with the 1999 Chi-Chi earthquake based on the following characteristics: (1) a beddingparallel thrust fault with a dip of $20-30^{\circ}$ and a dip direction of $105^{\circ}$; (2) low resistivity; (3) low density, P-wave velocity, and S-wave velocity; (4) high Poisson ratio; (5) low energy and velocity anisotropy; (6) increasing gas $\left(\mathrm{CO}_{2}\right.$ and $\mathrm{CH}_{4}$ ) emissions; and (7) rich in smectite within the slip zone. This fault zone is denoted as the FZA1111.

Continuous core samples were taken at the two deep holes. Several authors (e.g., Kuo et al. 2005, 2009; Hung et al. 2007; Sone et al. 2007; Song et al. 2007b; Yeh et al. 2007; Wu et al. 2008) analyzed the clay minerals of the core samples (smectite, illite, kaolinite, chlorite, and pseudotachylites), and also described lithology, characteristics and structures of the fault zone in detail. Fault breccia and a gouge, with an increase in the degree of fracturing from top to bottom, were found within the Chinsui shale at depths of $1105-1115 \mathrm{~m}$. According to the presence of an ultrafine grained fault gouge and a large fracture density, Ma et al. (2006) called a 12-cm thick zone at depths of 1111.23 $1111.35 \mathrm{~m}$ the primary slip zone (PSZ). The traced fissures of PSZ are shown in Fig. 3. The PSZ consists of several slip sub-zones associated with repeated past events. Each slip sub-zone has a thickness of about $2-3 \mathrm{~cm}$, with $5-\mathrm{mm}$ thick ultra-fine grains at the bottom. Hung et al. (2007) found that the PSZ has low seismic velocities and low electric resistivity. In addition, the thickness of the slip zone equivalent to the PSZ found at nearby sites is $50-300$ micron on the fault surface near the drilled site and $7 \mathrm{~mm}$ at a depth of $330 \mathrm{~m}$ in a shallow hole. Therefore, the thickness of the PSZ increases more or less with depth, at least, in the topmost $2 \mathrm{~km}$. The bottom $2-\mathrm{cm}$ thick sub-zone, which is least deformed, was named as the major slip zone (MSZ) and regarded as the actual slip zone of this earthquake by Ma et al. (2006).

The core samples obtained from the PSZ were analyzed in detail. Several authors (Kuo et al. 2005; Sone et al. 2007; Song et al. 2007b; and Kuo et al. 2009) observed numerous slip sub-zones within the PSZ and black materials at a depth of 1111.29 - $1111.35 \mathrm{~m}$. Using the X-Ray Diffraction (XRD) method, Song et al. (2007b) found that: (1) smectite traces are rare or absent in the most part of the slip sub-zones, but rich in the 1111.29-m black materials; (2) the contents of other clay minerals (illite, chlorite, and kaolinite) are rich, yet decrease to zero in black materials; and (3) kaolinite is absent at two narrow depths of the 1111-m slip sub-zones. They inferred that smectite was not retrograded from illite and might be devitrified from glasses, because of a lack of a smectite-illite mixed layer. They also assumed that clay minerals in the PSZ could be resulted from devitrification of pseudotachylytes. It is consistent with glass which is identified by Transmission Electron Microscopy (TEM) in the black layer of the 1111-m zone. From the XRD method, Ma et al. (2006) observed that the minerals in the MSZ are composed of about $70 \%$ of quartz, $5 \%$ of feldspar, and $25 \%$ of clay minerals. There is a significant difference in the depth distribution of clay minerals in the PSZ.

Geophysical well-loggings were performed from 944 to $1866 \mathrm{~m}$ at Hole-A to measure the P- and S-wave velocities, density, gamma ray, electrical resistivity, and temperature (Hung et al. 2007). In addition, laboratory experiments were also done on the core samples obtained from this hole to measure the mechanical, thermal, hydraulic, and electric and magnetic parameters. Based on seismic velocities well-logged by Hung et al. (2007), porosity and permeabil- 


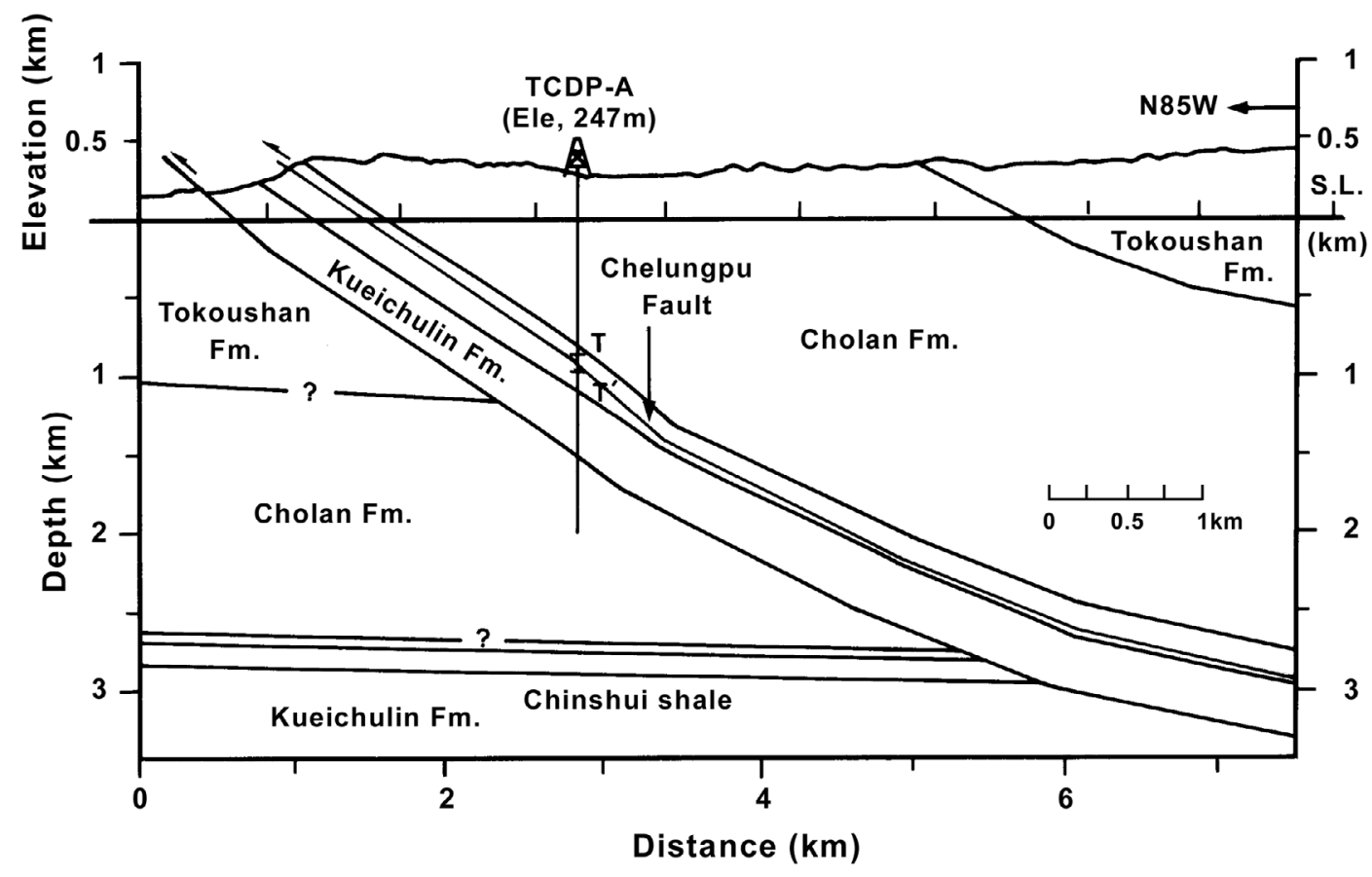

Fig. 2. Structural profile across Hole-A [reproduced from Hung et al. (2007)].

ity measured in laboratory settings by Dong et al. (2010), and density measured in laboratory settings by Hsu (2007), Wang et al. (2009) studied the depth variations of several parameters (including $\mathrm{P}$ - and $\mathrm{S}$-wave velocities, ratio of $\mathrm{P}$ to $\mathrm{S}$-wave velocities, porosity, and permeability) and the correlations between $\mathrm{P}$ - and $\mathrm{S}$-wave velocities and between seismic velocities and porosity. In addition, they also evaluated the bulk and shear modulus. The depth variations in seismic velocities, density, porosity, permeability, gamma ray, electrical resistivity etc. can represent not only the general trend of lithology but also its finer differentiations. Wu et al. (2008) conducted core-log integration studies of lithology at Hole-A. In addition, Yabe et al. (2008) measured in-situ stresses at Hole-A. Their main results are: (1) the direction of the maximum compression, $\mathrm{S}_{\mathrm{H} \max }$, is parallel to the slip of the Chi-Chi earthquake and agrees with those of local and regional tectonics; (2) significant aspects of the stresses are identical to those of paleostresses; (3) the horizontal differential stresses were remarkably reduced just above the FZ1111.

At Hole-B, Hirono et al. (2007b) recognized three fault zones, i.e., FZB1136 (1134 - 1137 m), FZB1194 (1194 - $1197 \mathrm{~m})$, and FZB1243 (1242 - $1244 \mathrm{~m})$. The FZB1136 which is equivalent to the FZA1111 at Hole-A has been regarded as the fault zone associated with the 1999 Chi-Chi earthquake. Hirono et al. (2006a, b, 2007b) made nondestructive physical property measurements, including GRA wet-bulk density, magnetic susceptibility, natural gamma ray, porosity, and discrete density. They also correlated those measurements to lithology. Matsubayashi et al. (2005)

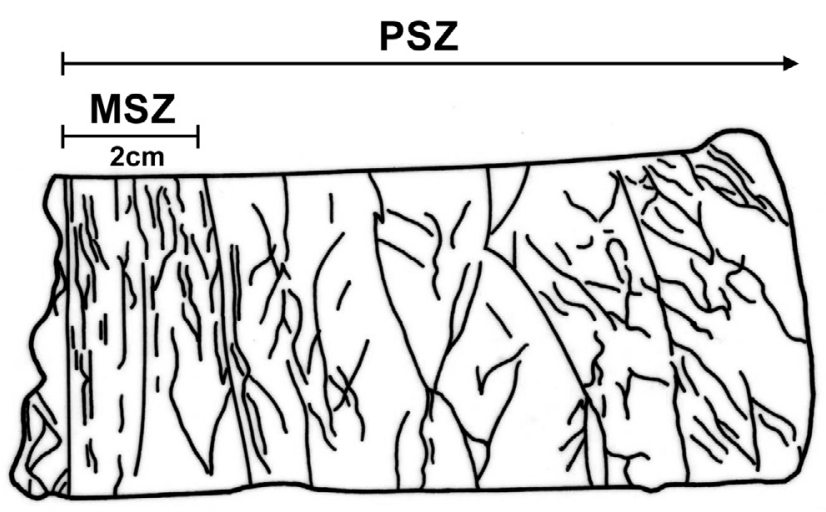

Fig. 3. The traced fractures in 12-cm thick core sample of the Primary Slip Zone (PSZ) drilled from Hole-A. The arrow points to the upward direction. The Major Slip Zone (denoted by MSZ) is at the bottom $2 \mathrm{~cm}$ (This figure is reproduced from Ma et al. 2006).

measured thermal conductivity on the core samples obtained in two depth ranges. Mizoguchi et al. (2008) measured the friction coefficients on the core samples using the gas-medium, high-pressure and high-temperature tri-axial apparatus. Lin et al. (2008) applied the time domain reflectometry (TDR) technique to measure the volumetric water content which is defined as the pore-water volume divided by the total volume of a rock sample, for core samples in the depth range $950-1350 \mathrm{~m}$.

Clearly, the borings succeeded in measuring and thus characterizing in-situ rock properties and around the fault zone after the earthquake. Detailed analyses of physical 
parameters, including mechanical, thermal, hydraulic, electric, and magnetic parameters, measured either on the core samples or through well-loggings will help us to quantitatively investigate some seismological issues as addressed by Mori et al. (2002). However, results have been published in different articles and reports. It is not convenient for earth scientists who are interested in and/or have to use those data sets. In this work, the measured results of physical properties at the shallow and deep holes are compiled together and reviewed. In addition, the correlations between a few physical parameters will also be reported. Note that chemical properties are out of the scope of this study.

\section{PHYSICAL PROPERTIES}

The measured results of physical parameters will be described below and summarized in Table 1. In the following, the depth from the ground surface is denoted by $\mathrm{z}$.

Table 1. Measured values of physical parameters at shallow and deep holes.

\begin{tabular}{|c|c|c|c|}
\hline Physical Parameters & North & South & Remarks \\
\hline \multicolumn{4}{|l|}{ Dip angle (degree) } \\
\hline \multirow[t]{3}{*}{ Deep Hole A (1111 m) } & 30 & & Hung et al. (2007) \\
\hline & 20 & & Yeh et al. (2007) \\
\hline & 20 & & Ma et al. (2001) \\
\hline \multicolumn{4}{|l|}{ Dip direction (degree) } \\
\hline Deep Hole A (1111 m) & 105 & & Yeh et al. (2007) \\
\hline \multicolumn{4}{|l|}{ Slip vector (degree) } \\
\hline Deep Hole A (1111 m) & 66 & & Ma et al. (2001) \\
\hline \multicolumn{4}{|l|}{ Dislocation (m) } \\
\hline \multirow[t]{2}{*}{ Deep Hole A (1111 m) } & 12 & & Ma et al. (2001) \\
\hline & 4.24 & & CGS (1999) \\
\hline \multicolumn{4}{|l|}{ Grain size $(\mu \mathrm{m})$} \\
\hline In the MSZ & $0.05-0.1$ & & Ma et al. (2006) \\
\hline $889-892.2 \mathrm{~m}$ & $56.2 \pm 16.3$ & & Oku et al. (2007) \\
\hline \multicolumn{4}{|l|}{ Friction coefficient } \\
\hline Shallow holes & $0.1-0.2(0.15)$ & $0.7-1.0(0.85)$ & Mori (2004) \\
\hline Shallow hole & & & Tanaka et al. (2006) \\
\hline upper slip zone & 0.13 & & \\
\hline lower slip zone & 0.12 & & \\
\hline Deep Hole A (inside the range of $\pm 60 \mathrm{~m}$ from the slip zone) & 0.08 & & Kano et al. (2006) \\
\hline Deep Hole A $(\sim 837$ m) & $0.68-0.87$ & & Chen et al. (2005) \\
\hline \multirow[t]{3}{*}{ Deep Hole A (500 - 1750 m) } & $0.5-0.7$ & & Lockner et al. $(2005,2007)$ \\
\hline & $1 \geq 0.35$ & & Sone et al. (2005) \\
\hline & 0.04 or 0.05 & & Hirono et al. (2007a) \\
\hline Deep Hole B (1136 m) & 0.3 & & Mizoguchi et al. (2008) \\
\hline \multicolumn{4}{|l|}{ Characteristic slip displacement (m) } \\
\hline Shallow hole & 1 & & Tanaka et al. (2002) \\
\hline Deep Hole A (1153 m) & $5-10$ & & Sone et al. (2005) \\
\hline Chelungpu fault (2 - $8 \mathrm{~km})$ & $1-10$ & & Tanikawa et al. (2005) \\
\hline Shangtung fault (2 - $8 \mathrm{~km})$ & $0.3-1$ & & Tanikawa et al. (2005) \\
\hline \multicolumn{4}{|l|}{ Elastic modulus (GPa) } \\
\hline Deep Hole A (889 - 892.2 m) & $13.7 \pm 0.2$ & & Oku et al. (2007) \\
\hline
\end{tabular}


Table 1. (Continued)

\begin{tabular}{|c|c|c|c|}
\hline Physical Parameters & North & South & Remarks \\
\hline \multicolumn{4}{|l|}{ Young modulus (GPa) } \\
\hline Deep Hole A (739 - 1316 m) & $7-13$ & & Yabe et al. (2008) \\
\hline \multicolumn{4}{|l|}{ Bulk Modulus (dry state) (GPa) } \\
\hline Deep Hole A (944 - 1866 m) & 40.89 & & Wang et al. (2009) \\
\hline \multicolumn{4}{|l|}{ Shear Modulus (dry state) (GPa) } \\
\hline Deep Hole A (944 - 1866 m) & 19.16 & & Wang et al. (2009) \\
\hline \multicolumn{4}{|l|}{$\mathrm{v}_{\mathrm{p}}\left(\mathrm{km} \mathrm{s}^{-1}\right)$} \\
\hline Deep Hole A (944 - 1866 m) & $2.30-5.52$ & & Hung et al. (2007) \\
\hline \multicolumn{4}{|l|}{$\mathrm{v}_{\mathrm{s}}\left(\mathrm{km} \mathrm{s}^{-1}\right)$} \\
\hline Deep Hole A (944 - 1866 m) & $1.06-3.01$ & & Hung et al. (2007) \\
\hline \multicolumn{4}{|l|}{$\mathrm{v}_{\mathrm{p}} / \mathrm{v}_{\mathrm{s}}$} \\
\hline Deep Hole A (944 - 1866 m) & $1.50-3.05$ & & Hung et al. (2007) \\
\hline \multicolumn{4}{|l|}{ Poisson's ratio } \\
\hline Deep Hole A (1111 m) & $0.35-0.40$ & & Hung et al. (2007) \\
\hline Deep Hole A (889 - 892.2 m) & $0.13 \pm 0.01$ & & Oku et al. (2007) \\
\hline \multicolumn{4}{|l|}{ Density $\left(\mathrm{kg} \mathrm{m}^{-3}\right)$} \\
\hline Shallow holes & $<3000$ & $1500-3000$ & Tanaka et al. (2002) \\
\hline Shallow hole & $2245 \pm 58$ & & Tanaka et al. (2006) \\
\hline Deep Hole A (1111 m) & 2200 & & Kano et al. (2006) \\
\hline Deep Hole A & & & Hsu (2007) \\
\hline The Cholan Formation & $2300-2700$ & & \\
\hline The Chinshui Formation & $2300-2700$ & & \\
\hline The Kueichulin Formation & $2200-2600$ & & \\
\hline Deep Hole A (1000 - 1300 m) & $2200-2800$ & & Tanaka et al. (2007) \\
\hline Deep Hole A (889 - 892.2 m) & $2594 \pm 15$ & & Oku et al. (2007) \\
\hline Deep Hole B & & & Hirono et al. (2007b) \\
\hline 1136 m (outside the BGZ) & $2400-2700$ & & \\
\hline 1136 m (inside the BGZ) & $2000-2400$ & & \\
\hline 1194 m (outside the BGZ) & $2000-2700$ & & \\
\hline 1194 m (inside the BGZ) & $2200-2400$ & & \\
\hline 1243 m (outside the BGZ) & $2100-2700$ & & \\
\hline $1243 \mathrm{~m}$ (inside the BGZ) & $2200-2500$ & & \\
\hline \multicolumn{4}{|l|}{ Water Content } \\
\hline Shallow hole (225 m) & $45 \%$ & & Tanaka et al. (2002) \\
\hline Deep Hole B & & & Matsubayashi et al. (2005) \\
\hline $1142-1170 m$ & $(15-26) \%$ & & \\
\hline $1200-1235 \mathrm{~m}$ & $(15-26) \%$ & & \\
\hline Deep Hole B (950 - 1350 m) & $(2-30) \%$ & & Lin et al. (2008) \\
\hline
\end{tabular}


Table 1. (Continued)

\begin{tabular}{|c|c|c|c|}
\hline Physical Parameters & North & South & Remarks \\
\hline \multicolumn{4}{|l|}{ Permeability $\left(\mathrm{m}^{2}\right)$} \\
\hline Shallow holes & $10^{-16}-10^{-19}(1-100 \mathrm{MPa})$ & $10^{-14}-10^{-17}(1-100 \mathrm{MPa})$ & Tanikawa et al. (2004) \\
\hline Deep Hole A & & & Chen et al. (2005) \\
\hline Bioturbated sandstone (588m) & $10^{-14}(5-20 \mathrm{MPa})$ & & \\
\hline Shaly siltsandstone (837 m) & $10^{-18}-10^{-19}(5-40 \mathrm{MPa})$ & & \\
\hline Deep Hole A $(1111 \pm 30$ m) & $(0.4-7.0) \times 10^{-20}(15.5 \mathrm{MPa})$ & & Lockner et al. (2005) \\
\hline Deep Hole A (954.1 - 1315.3 m) & $10^{-19}-10^{-21}(6.5-15.5 \mathrm{MPa})$ & & Lockner et al. (2007) \\
\hline Deep Hole A (482 - 1316 m) & & & Takahashi et al. (2005) \\
\hline Clean sandstone & $10^{-13}(25 \mathrm{MPa})$ & & \\
\hline Silty sandstone & $10^{-17}(25 \mathrm{MPa})$ & & \\
\hline Deep Hole A (1153 m) & $10^{-14}-10^{-18}(1-140 \mathrm{MPa})$ & & Sone et al. (2005) \\
\hline Depp Hole A & & & Dong et al. (2010) \\
\hline Sandstone & $10^{-13}-10^{-14}(3-140 \mathrm{MPa})$ & & \\
\hline Silty-shale & $10^{-16}-10^{-19}(3-140 \mathrm{MPa})$ & & \\
\hline Between Hole A and Hole B & $10^{-16}-10^{-18}$ & & Doan et al. (2006) \\
\hline Chenlungpu fault gouge & $10^{-15}-10^{-17}$ & & Tanikawa et al. (2005) \\
\hline Shuangtung fault gouge & $10^{-17}-10^{-19}$ & & Tanikawa et al. (2005) \\
\hline \multicolumn{4}{|l|}{ Porosity } \\
\hline Shallow holes & $(10-80) \%$ & & Tanaka et al. (2002) \\
\hline Deep Hole A (450 - 1300 m) & & $(10-80) \%$ & Lu et al. (2005) \\
\hline Siltstone & $2 \%(67-73 \mathrm{MPa})$ & & \\
\hline Fossil-rich sandstone & $6 \%(61-65 \mathrm{MPa})$ & & \\
\hline Sandstone & $15 \%(8-11 \mathrm{MPa})$ & & \\
\hline Deep Hole A & & & Chen et al. (2005) \\
\hline Bioturbated sandstone (588m) & $(15-18) \%$ & & \\
\hline Shaly siltsandstone (837 m) & $(4-5) \%$ & & \\
\hline Deep Hole A (1000 - 1300 m) & $(6-42) \%$ & & Tanaka et al. (2007) \\
\hline Deep Hole A (889 - 892.2 m) & $(6.9 \pm 0.8) \%$ & & Oku et al. (2007) \\
\hline Deep Hole A & & & Dong et al. (2010) \\
\hline Siltstone & $(15-19) \%$ & & \\
\hline Sandstone & $(8-14) \%$ & & \\
\hline Deep Hole B (948.42 - 1252.60 m) & $(5-30) \%$ & & Hirono et al. (2007b) \\
\hline \multicolumn{4}{|l|}{ Hydraulic Diffusivity $\left(\mathrm{m}^{2} \mathrm{~s}^{-1}\right)$} \\
\hline Between Hole A and Hole B & $(7 \pm 1) \times 10^{-5}$ & & Doan et al. (2006) \\
\hline \multicolumn{4}{|l|}{ Transmissivity $\left(\mathrm{m}^{2} \mathrm{~s}^{-1}\right)$} \\
\hline Between Hole A and Hole B & $10^{-11}-10^{-9}$ & & Doan et al. (2006) \\
\hline \multicolumn{4}{|l|}{ Storativity } \\
\hline Between Hole A and Hole B & $10^{-7}-10^{-5}$ & & Doan et al. (2006) \\
\hline \multicolumn{4}{|l|}{ Specific storage $\left(\mathrm{Pa}^{-1}\right)$} \\
\hline Deep Hole A & $(1.3-7) \times 10^{-11}$ & & Lockner et al. (2005) \\
\hline Deep Hole A & $10^{-9}-10^{-10}$ & & Tanikawa et al. (2005) \\
\hline
\end{tabular}


Table 1. (Continued)

\begin{tabular}{|c|c|c|c|}
\hline Physical Parameters & North & South & Remarks \\
\hline \multicolumn{4}{|l|}{ Thermal gradient $\left({ }^{\circ} \mathrm{C} \mathrm{km}^{-1}\right)$} \\
\hline Shallow hole & $5-6$ & & Tanaka et al. (2006) \\
\hline Deep Hole A (500 - 1275 m) & 9 & & Hung et al. (2007) \\
\hline Deep Hole A (1275 - 1842 m) & 7 & & \\
\hline \multicolumn{4}{|l|}{ Specific heat $\left(\mathrm{J} \mathrm{kg}^{-1}{ }^{\circ} \mathrm{C}^{-1}\right)$} \\
\hline Shallow holes & $1.14 \times 10^{3}$ & $1.14 \times 10^{3}$ & Mori (2004) \\
\hline Shallow hole & $(3.26 \pm 0.42) \times 10^{2}$ & & Tanaka et al. (2006) \\
\hline Deep Hole A (inside the range of $\pm 60 \mathrm{~m}$ from the slip zone) & $1.7 \times 10^{3}$ & & Kano et al. (2006) \\
\hline Deep Hole A (1000 - 1300 m) & $(0.3-1.0) \times 10^{3}$ & & Tanaka et al. (2007) \\
\hline \multicolumn{4}{|l|}{ Thermal diffusivity $\left(\mathrm{m}^{2} \mathrm{~s}^{-1}\right)$} \\
\hline Shallow holes & $2.0 \times 10^{-6}$ & $5.0 \times 10^{-7}$ & Mori (2004) \\
\hline Shallow hole & $(1.47 \pm 0.04) \times 10^{-6}$ & & Tanaka et al. (2006) \\
\hline Deep Hole A (inside the range of $\pm 60 \mathrm{~m}$ from the slip zone) & $0.34 \times 10^{-6}$ & & Kano et al. (2006) \\
\hline Deep Hole A (inside the range of $\pm 60 \mathrm{~m}$ from the slip zone) & $(0.8-2.0) \times 10^{-6}$ & & Tanaka et al. (2007) \\
\hline \multicolumn{4}{|l|}{ Thermal conductivity $\left(\mathrm{J} \mathrm{kg}^{-1} \mathrm{~s}^{-1}{ }^{\circ} \mathrm{C}^{-1}\right)$} \\
\hline Deep Hole A & 1.3 & & Kano et al. (2006) \\
\hline \multicolumn{4}{|l|}{ Deep Hole A } \\
\hline Host and fractured rocks & $1.0-3.0$ & & Tanaka et al. (2007) \\
\hline Slip zone & 1.0 & & \\
\hline \multicolumn{4}{|l|}{ Deep Hole B } \\
\hline $1142-1170 m$ & $2.2-3.7$ & & Matsubayashi et al. (2005) \\
\hline $1200-1235 \mathrm{~m}$ & $2.2-3.7$ & & Matsubayashi et al. (2005) \\
\hline
\end{tabular}

Magnetic Susceptibility (SI)

Deep Hole B

Volume susceptibility

Hirono et al. (2006a, 2007b)

$1136 \mathrm{~m}$ (outside the BGZ)

$(30-60) \times 10^{-5}$

$1136 \mathrm{~m}$ (inside the BGZ)

$(50-80) \times 10^{-5}$

1194 m (outside the BGZ)

$(28-52) \times 10^{-5}$

$1194 \mathrm{~m}$ (inside the BGZ)

$50 \times 10^{-5}$

$1243 \mathrm{~m}$ (outside the BGZ)

$(27-54) \times 10^{-5}$

$1243 \mathrm{~m}$ (inside the BGZ)

$(40-55) \times 10^{-5}$

The Cholan Formation

$(20-80) \times 10^{-8}$

The Chinshui Shale

$(30-150) \times 10^{-8}$

The Kueichulin Formation

$(20-200) \times 10^{-5}$

Mass susceptibility $\left(\mathrm{m}^{3} \mathrm{~kg}^{-1}\right)$

$1134 \mathrm{~m}$

$(10-500) \times 10^{-8}$

Tanikawa et al. (2008)

$\left(0-900^{\circ} \mathrm{C}\right)$

Electric Resivisity (ohm-m)

Shallow hole

$5-32$

$10-30$

Tanaka et al. (2002)

Deep Hole A (944 - 1866 m)

Hung et al. (2007) 


\subsection{The Primary Slip Zone}

From field observations, a slip in an earthquake is considered to be localized and occurs primarily within a thin shear zone, < 0.001 - $0.005 \mathrm{~m}$ (e.g., Chester and Chester 1998; Chester et al. 1993; Sibson 2003; Rice 2006). Each slip sub-zone in the core samples at Hole-A has a thickness of about $0.02-0.03 \mathrm{~m}$, with $0.005-\mathrm{m}$ thick ultra-fine grains at the bottom. Ma et al. (2006) found a narrow slip zone of $\sim 0.003 \mathrm{~m}$ inside the MSZ. In Fig. 3, the fissures in the bottom $0.001 \mathrm{~m}$ show a linear pattern. The pattern of fissures becomes complex from bottom to top.

\subsection{Mechanical Parameters}

\subsubsection{Fault Geometry}

At the shallow holes, Huang et al. (2002) recognized two possible fracture zones which are at 225 - 330 and 177 $180 \mathrm{~m}$, respectively, in the northern and southern boreholes. The dip angles Hung et al. (2007) and Yeh et al. (2007) recognized 10 - 12 fault zones at deep Hole-A from the core samples and measured their dips FMI (or FMS) logs. At the FZA1111, the average dip is $20-30^{\circ}$ towards the SE and the dip direction is $105^{\circ}$. The dip angle, slip vector, and displacement, $\mathrm{D}$, on a $5 \times 5 \mathrm{~km}^{2}$ subfault covering the FZA1111 inferred by Ma et al. (2001) from earthquake data are, respectively, $20^{\circ}, 66^{\circ}$, and $12 \mathrm{~m}$. Since the value of $\mathrm{D}=12 \mathrm{~m}$ is an average displacement over the subfault, it becomes problematic to take it to be the slip displacement of the drill site. From the surface displacements measured at several locations near the drill site retrieved from field surveys (CGS 1999), the average displacement is $4.24 \mathrm{~m}$.

\subsubsection{Grain Size}

Ma et al. (2006) measured the grain size of the MSZ using the transmission electron microscope (TEM) and scanning electron microscope (SEM). Results are $0.05-0.1 \mu \mathrm{m}$. Oku et al. (2007) measured the grain size for core samples at depths between $889-892.2 \mathrm{~m}$. The values are $56.2 \pm 16.3 \mu \mathrm{m}$. Results seem to suggest that the grain size is smaller inside than outside the MSZ.

\subsubsection{Friction Coefficient, Characteristic Slip Displace- ment, and Elastic Modulus}

For the two shallow holes, Mori (2004) estimated the friction coefficient, $\mu_{\mathrm{f}}$, on the individual fault planes. Results are $0.7-1.0$, with an average 0.85 , at $\mathrm{z}=182 \mathrm{~m}$ in the southern hole and $0.1-0.2$, with an average 0.15 , at $\mathrm{z}=$ $320 \mathrm{~m}$ at the northern hole. The average value for the two holes is 0.45 . From the spatial distribution of temperature, Tanaka et al. (2006) proposed that during faulting there were two slip subzones at the northern hole. They also evaluated the values of $\mu_{\mathrm{f}}: 0.13$ for the upper subzone and 0.12 for the lower subzone.

At Hole-A, the values of $\mu_{\mathrm{f}}$ measured by Lockner et al. $(2005,2007)$ from the core samples are $0.5-0.7$ in the PSZ, with the smallest in the MSZ. Sone et al. (2005) inferred that $\mu_{\mathrm{f}}$ dropped from 1 to 0.35 during the earthquake. From the spatial distribution of temperature rise, Kano et al. (2006) inferred that the optimum value of $\mu_{\mathrm{f}}$ is 0.08 during faulting. At Hole-B, Hirono et al. (2007b) inferred that during the earthquake the dynamic shear stress was deduced to be 1.31 $\mathrm{MPa}$ and thus $\mu_{\mathrm{f}}=0.04$ or 0.05 under two different stress conditions. Mizoguchi et al. (2008) found $\mu_{\mathrm{f}}=0.3$ for the black gouge zone (BGZ) and $\mu_{\mathrm{f}}=0.5$ for un-deformed host rocks at FZB1136. Obviously, $\mu_{\mathrm{f}}$ is not a function of depth.

Tanaka et al. (2002) and Tanikawa et al. (2004) measured the characteristic slip distance from the rock mechanics experiments. The former observed $D_{c}=\sim 1 \mathrm{~m}$ for the northern hole. The latter found that in the depth range $28 \mathrm{~km}$, thermal pressurization is least effective on the Chelungpu fault when $D_{c}=1-10 \mathrm{~m}$, and is most effective on the Shangtung fault when $\mathrm{D}_{\mathrm{c}}=0.3-1 \mathrm{~m}$. Sone et al. (2005) obtained $D_{c}=5-10 \mathrm{~m}$ on the fault plane at Hole-A. Tanikawa et al. (2005) gained $\mathrm{D}_{\mathrm{c}}=1-10 \mathrm{~m}$.

Oku et al. (2007) measured the elastic modulus of rock samples at $889-892.2 \mathrm{~m}$. The measured values are $13.7 \pm$ $0.2 \mathrm{GPa}$. However, they did not clearly explain which kind of elastic modulus was made. From the stress memory of rocks revealed at five depths from 739 to $1316 \mathrm{~m}$ ), Yabe et al. (2008) measured the Young modulus. Results are between 7 and $13 \mathrm{GPa}$.

\subsubsection{Seismic Velocities}

Seismic velocities ( $\mathrm{P}$ - and $\mathrm{S}$-wave velocities, denoted by $\mathrm{v}_{\mathrm{p}}$ and $\mathrm{v}_{\mathrm{s}}$, respectively, hereafter) are two major parameters representing mechanical properties of subsurface geological structures. The two parameters are in terms of bulk modulus, $\mathrm{K}$, shear modulus, $\mu$, and density, $\rho$, in the individual forms: $v_{p}=[(K+4 \mu / 3) / \rho]^{1 / 2}$ and $v_{s}=(\mu / \rho)^{1 / 2}$. The ratio of P- to S-wave velocities is directly related to the Poisson ratio, $v$, which equals $\left[0.5\left(\mathrm{v}_{\mathrm{p}} / \mathrm{v}_{\mathrm{s}}\right)^{2}-2\right] /\left[\left(\mathrm{v}_{\mathrm{p}} / \mathrm{v}_{\mathrm{s}}\right)^{2}-1\right]$. Hence, it is important to directly measure or indirectly infer seismic velocities. The values of $\mathrm{v}_{\mathrm{p}}$ and $\mathrm{v}_{\mathrm{s}}$ were well-logged only at Hole-A in the depth range $494-1866 \mathrm{~m}$ (Hung et al. 2007) the measurement interval is $12.5 \mathrm{~cm}$ for $\mathrm{z}<1297.23$ $\mathrm{m}$ and $15 \mathrm{~cm}$ for $\mathrm{z}>1297.23 \mathrm{~m}$. The ranges of well-logged seismic velocities are $2.30-5.52 \mathrm{~km} \mathrm{~s}^{-1}$ for $\mathrm{v}_{\mathrm{p}}$ and 1.06 $3.01 \mathrm{~km} \mathrm{~s}^{-1}$ for $\mathrm{v}_{\mathrm{s}}$. Hence, the range of $\mathrm{v}_{\mathrm{p}} / \mathrm{v}_{\mathrm{s}}$ is $1.50-3.05$. Hung et al. (2007) also calculated the Poisson ratio; the results are between 0.35 and 0.4 .

The depth variations of $v_{p}$ and $v_{s}$ in this depth range are plotted in the upper diagram of Fig. 4a. Averages of $v_{p}$, $\mathrm{v}_{\mathrm{s}}$, and $\mathrm{v}_{\mathrm{p}} / \mathrm{v}_{\mathrm{s}}$ are, respectively, $3.87 \mathrm{~km} \mathrm{~s}^{-1}, 1.89 \mathrm{~km} \mathrm{~s}^{-1}$, and 2.07 (Wang et al. 2009). Averages of $\mathrm{v}_{\mathrm{p}}$ and $\mathrm{v}_{\mathrm{s}}$ are displayed 
by horizontal dashed lines and average $\mathrm{v}_{\mathrm{p}} / \mathrm{v}_{\mathrm{s}}$ by a horizontal dashed line in Fig. 4a. The depth range of the PSZ is displayed by two vertical dotted lines.

To clearly display detailed information near the PSZ, the variations of $\mathrm{v}_{\mathrm{p}}, \mathrm{v}_{\mathrm{s}}$, and $\mathrm{v}_{\mathrm{p}} / \mathrm{v}_{\mathrm{s}}$ in the depth range of 1110 - 1112 m (Hung et al. 2007; Wang et al. 2009) are plotted as a function of depth (Fig. 4b). Inside the PSZ, $v_{p}$ and $v_{s}$ were well-logged only at $1111.31 \mathrm{~m}$. The values of $\mathrm{v}_{\mathrm{p}}, \mathrm{v}_{\mathrm{s}}$, and $\mathrm{v}_{\mathrm{p}} / \mathrm{v}_{\mathrm{s}}$ are $3.27 \mathrm{~km} \mathrm{~s}^{-1}, 1.41 \mathrm{~km} \mathrm{~s}^{-1}$, and 2.32 , respectively. Wang et al. (2009) calculated the differences between these values and their individual averages, and reported the values of $-0.60 \mathrm{~km} \mathrm{~s}^{-1}$ for $\mathrm{v}_{\mathrm{p}},-0.48 \mathrm{~km} \mathrm{~s}^{-1}$ for $\mathrm{v}_{\mathrm{s}}$, and 0.25 for $\mathrm{v}_{\mathrm{p}} / \mathrm{v}_{\mathrm{s}}$. Obviously, in the PSZ $v_{p}$ and $v_{s}$ are lower and $v_{p} / v_{s}$ is higher than the individual averages.

Figure $4 \mathrm{a}$ shows the depth variations in $\mathrm{v}_{\mathrm{p}}$ or $\mathrm{v}_{\mathrm{s}}$. The plot can be separated into four depth ranges: 494 - $1013 \mathrm{~m}$ (in the Cholan Formation), 1013 - $1300 \mathrm{~m}$ (in the Chinshui Shale), 1300 - 1707 m (in the Kueichulin Formation), and 1707 - 1866 m (in the repeated Cholan Formation). The four ranges are separated by three thin vertical lines in Fig. 4a. In each depth range, $\mathrm{v}_{\mathrm{p}}$ or $\mathrm{v}_{\mathrm{s}}$ are almost linearly dependent on the depth, z, as suggested by Slotnick (1936) in the following form: $v=(a \pm \delta a)+(b \pm \delta b) z$, where $v$ is either $v_{p}$ or $\mathrm{v}_{\mathrm{s}}$, $\mathrm{a}$ and $\mathrm{b}$ are two coefficients, and $\delta \mathrm{a}$ and $\delta \mathrm{b}$ are the standard errors of $a$ and $b$, respectively. The values of $a, \delta a, b$, and $\delta b$ are shown in Table 2 and the equations are depicted in Fig. 4a by dashed line segments.

On the basis of the first-order polynomial (Boore and Joyner 1997):

$\mathrm{v}(\mathrm{z})=\mathrm{cz} \mathrm{z}^{\mathrm{d}}$

where $\mathrm{c}$ and $\mathrm{d}$ are two constant coefficients, Huang et al. (2007) studied the depth functions of $v_{p}$ and $v_{s}$ from welllogging data at Hole-A. But, they did not show the depth functions. According to Eq. (1), Wang et al. (2009) inferred the depth functions for the first three depth ranges. The resultant first-order polynomials are

$\mathrm{v}_{\mathrm{p}}(\mathrm{z})=1.68 \mathrm{z}^{0.12}$

for $\mathrm{v}_{\mathrm{p}}$ and

$\mathrm{V}_{\mathrm{s}}(\mathrm{z})=0.29 \mathrm{z}^{0.27}$

for $\mathrm{v}_{\mathrm{s}}$. The two depth functions are displayed in Fig. 4a by solid lines. Except for the depth range 1707 - $1866 \mathrm{~m}$, the solid lines are close to the dashed lines, which represent the average seismic velocities. (a)

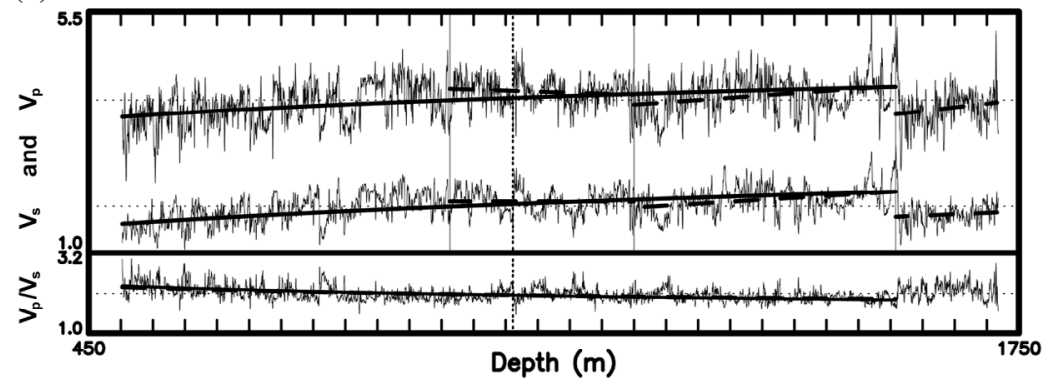

(b)

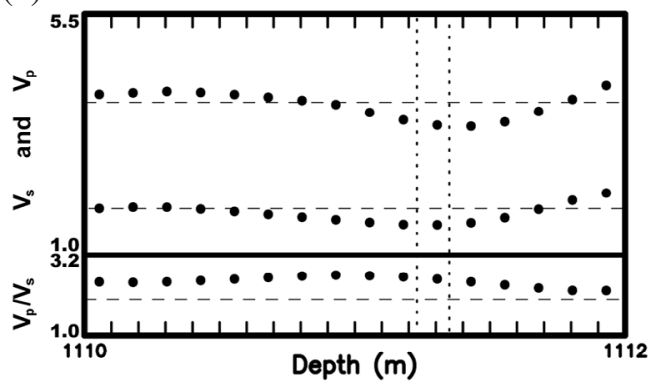

Fig. 4. The depth variations of $v_{p}, v_{s}$, and $v_{p} / v_{s}$ : (a) for the depth range of $502.18-1868.01 \mathrm{~m}$; and (b) for the depth range of $1110-1112 \mathrm{~m}$. The average values of $\mathrm{v}_{\mathrm{p}}, \mathrm{v}_{\mathrm{s}}$, and $\mathrm{v}_{\mathrm{p}} / \mathrm{v}_{\mathrm{s}}$ are denoted by horizontal dashed lines. The depth range of PSZ is displayed by two vertical dotted lines. In (a), the regression depth functions of $v_{p}$ and $v_{s}$ in four depth ranges, i.e., $494-1013,1013-1300,1300-1707$, and $1707-1866 \mathrm{~m}$ (separated by three thin vertical solid lines) are shown with dashed lines, and the regression depth functions of $\mathrm{v}_{\mathrm{p}}=1.68 \mathrm{z}^{0.12}$ and $\mathrm{v}_{\mathrm{s}}=0.29 \mathrm{z}^{0.27}(\mathrm{z}=$ depth) for 494 $1707 \mathrm{~m}$ are depicted by solid lines [from Wang et al. (2009)].

Table 2. The values of $a \pm \delta a$ and $b \pm \delta b$ of the regression linear equations of $v_{p}$ versus $z$ and $v_{s}$ versus $z$ for four depth ranges (in meters).

\begin{tabular}{|c|c|c|c|c|c|}
\hline & & $502-1013$ & $1013-1300$ & $1300-1707$ & 1707 - 1868 \\
\hline \multirow[b]{2}{*}{$\mathbf{v}_{\mathbf{p}}$} & $a \pm \delta a$ & $2.838 \pm 0.026$ & $4.446 \pm 0.083$ & $2.664 \pm 0.084$ & $1.226 \pm 0.420$ \\
\hline & $b \pm \delta b$ & $0.001 \pm 0.000$ & $0.000 \pm 0.000$ & $0.001 \pm 0.000$ & $0.001 \pm 0.000$ \\
\hline \multirow[b]{2}{*}{$\mathbf{v}_{\mathrm{s}}$} & $a \pm \delta a$ & $0.891 \pm 0.017$ & $1.957 \pm 0.005$ & $0.893 \pm 0.056$ & $0.815 \pm 0.277$ \\
\hline & $\mathrm{b} \pm \delta \mathrm{b}$ & $0.001 \pm 0.000$ & $0.000 \pm 0.000$ & $0.001 \pm 0.000$ & $0.001 \pm 0.000$ \\
\hline
\end{tabular}



tained

Dividing Eq. (2) by Eq. (3), Wang et al. (2009) ob-

$\mathrm{v}_{\mathrm{p}} / \mathrm{v}_{\mathrm{s}}=5.71 \mathrm{z}^{-0.15}$

Equation (4) is shown by a solid line in the depth range 494 - $1707 \mathrm{~m}$ in the lower diagram of Fig. 4a.

Hsu (2007) measured the values of $v_{p}$ and $v_{s}$ under an atmosphere pressure on the discrete rock samples from which the value of $\mathrm{v}_{\mathrm{p}} / \mathrm{v}_{\mathrm{s}}$ are calculated. Table 3 shows the values of $\mathrm{v}_{\mathrm{p}}, \mathrm{v}_{\mathrm{s}}$, and $\mathrm{v}_{\mathrm{p}} / \mathrm{v}_{\mathrm{s}}$ for the discrete samples. The values of $\mathrm{v}_{\mathrm{p}}$, $\mathrm{v}_{\mathrm{s}}$, and $\mathrm{v}_{\mathrm{p}} / \mathrm{v}_{\mathrm{s}}$ well-logged at or very close to the localities, where the rock samples were obtained, are listed in Table 3. The plots of the two kinds of values are displayed in Fig. 5: Fig. 5a for $\mathrm{v}_{\mathrm{p}}$, Fig. $5 b$ for $\mathrm{v}_{\mathrm{s}}$, and Fig. 5c for $\mathrm{v}_{\mathrm{p}} / \mathrm{v}_{\mathrm{s}}$. Obviously, for given data well-logged $v_{p}$ is larger than laboratory $v_{p}$ for all rock samples. Except for two rock samples, the difference between well-logged $\mathrm{v}_{\mathrm{s}}$ and laboratory-measured $\mathrm{v}_{\mathrm{s}}$ is small. Except for one rock sample, well-logged $v_{p} / v_{s}$ is larger than laboratory $\mathrm{v}_{\mathrm{p}} / \mathrm{v}_{\mathrm{s}}$, and the difference is small for four rock samples. Oku et al. (2007) measured the Poisson's ratio for the rock samples at $\mathrm{z}=889-892.2 \mathrm{~m}$. The values are $0.13 \pm 0.01$.

\subsubsection{Density}

At two shallow holes, Tanaka et al. (2002) well-logged density values using the gamma ray attenuation (GRA) method. This kind of density is denoted by $\rho_{\text {GRA }}$. Results are $\rho_{\mathrm{GRA}}<3000 \mathrm{~kg} \mathrm{~m}^{-3}$ at northern hole and $\rho_{\mathrm{GRA}}=1500$
- $3000 \mathrm{~kg} \mathrm{~m}^{-3}$ at the southern hole. At the northern shallow hole, Tanaka et al. (2006) measured the density values on six discrete core samples. This kind of density is denoted by $\rho_{\mathrm{ds}}$. The average $\rho_{\mathrm{ds}}$ is $2245 \pm 58 \mathrm{~kg} \mathrm{~m}^{-3}$.

Kano et al. (2006) reported $2.2 \times 10^{3} \mathrm{~kg} \mathrm{~m}^{-3}$ to be the density of the fault rocks near the FZ1111. Hsu (2007) directly measured the values of $\rho_{\mathrm{ds}}$ of discrete rock samples at Hole-A under an atmosphere pressure (Table 1). The measured values are in the range $(2.3-2.7) \times 10^{3} \mathrm{~kg} \mathrm{~m}^{-3}$ for the Cholan Formation, $(2.3-2.7) \times 10^{3} \mathrm{~kg} \mathrm{~m}^{-3}$ for the Chinshui Shale, and $(2.2-2.6) \times 10^{3} \mathrm{~kg} \mathrm{~m}^{-3}$ for the Kueichulin Formation. His measured values of $\rho_{\mathrm{ds}}$ are listed in Table 4 . The maximum difference among the values of $\rho_{\mathrm{ds}}$ is $0.48 \times 10^{3} \mathrm{~kg} \mathrm{~m}^{-3}$, and the average $\rho_{\mathrm{ds}}$ for all samples is $2.47 \times 10^{3} \mathrm{~kg} \mathrm{~m}^{-3}$. Hung et al. (2007) also measured the values of $\rho_{\mathrm{GRA}}$ at Hole-A. The values of $\rho_{\mathrm{GRA}}$ associated with Hsu's data are between 1800 and $2800 \mathrm{~kg} \mathrm{~m}^{-3}$ in the depth range $500-1750 \mathrm{~m}$. The values of $\rho_{\mathrm{GRA}}$ are also listed in Table 4. The plot of $\rho_{\text {GRA }}$ versus $\rho_{\mathrm{ds}}$ is shown in Fig. $5 \mathrm{~d}$. The data points for sandstone depart slightly from the bisection line, while those for silty-shale are around the line. Wang et al. (2009) calculated the difference between $\rho_{\mathrm{GRA}}$ and $\rho_{\mathrm{ds}}$, i.e., $\rho_{\mathrm{GRA}}-\rho_{\mathrm{ds}}$. Results range from -0.20 to $0.36 \mathrm{~g} \mathrm{~cm}^{-3}$, with a percentage error, i.e., $\left(\rho_{\mathrm{GRA}}-\rho_{\mathrm{ds}}\right) / \rho_{\mathrm{ds}}$, from $-7.72 \%$ to $16.51 \%$. The percentage is less than $17 \%$. The value of $\rho_{\mathrm{ds}}$ should be more accurate than that of $\rho_{\mathrm{GRA}}$, because the former was measured directly from the discrete rock sample and the latter inferred from gamma ray attenuation through an empirical formula. Tanaka et al. (2007) applied a He-gas type pycnometer (Accupic 1330, Micrometrics ${ }^{\mathrm{TM}}$ ) to

Table 3. The well-logged values of seismic velocities $\left(\mathrm{v}_{\mathrm{p}}\right.$ and $\left.\mathrm{v}_{\mathrm{s}}\right)$ and $\mathrm{v}_{\mathrm{p}} / \mathrm{v}_{\mathrm{s}}$ for ten discrete rock samples and the related values measured in the laboratory for six samples. The parameter $\mathrm{z}$ represents the depth of the locality where the rock samples were taken.

\begin{tabular}{|c|c|c|c|c|c|c|c|}
\hline \multirow{2}{*}{ Sample } & \multirow{2}{*}{$\mathbf{z}(\mathbf{m})$} & \multicolumn{3}{|c|}{ Well-logged } & \multicolumn{3}{|c|}{ Measured in Laboratory } \\
\hline & & $\mathbf{v}_{p}\left(\mathrm{~km} \mathrm{~s}^{-1}\right)$ & $\mathbf{v}_{\mathrm{s}}\left(\mathrm{km} \mathrm{s}^{-1}\right)$ & $\mathbf{v}_{\mathrm{p}} / \mathbf{v}_{\mathrm{s}}$ & $\mathbf{v}_{p}\left(\mathbf{k m ~ s}^{-1}\right)$ & $\mathbf{v}_{\mathrm{s}}\left(\mathrm{km} \mathrm{s}^{-1}\right)$ & $\mathbf{v}_{\mathrm{p}} / \mathbf{v}_{\mathrm{s}}$ \\
\hline R261sec2-1 & 915.24 & 3.76 & 1.87 & 2.01 & & & \\
\hline R261sec2-2 & 915.24 & 3.76 & 1.87 & 2.01 & & & \\
\hline R307sec1 & 1009.62 & 4.71 & 2.37 & 1.99 & & & \\
\hline R255sec2-1 & 902.68 & 4.07 & 2.02 & 2.02 & 3.28 & 1.92 & 1.71 \\
\hline $\mathrm{R} 255 \mathrm{sec} 2-2$ & 902.68 & 4.07 & 2.02 & 2.02 & & & \\
\hline $\mathrm{R} 287 \mathrm{sec} 1$ & 972.42 & 4.11 & 2.14 & 1.92 & 3.38 & 1.72 & 1.97 \\
\hline $\mathrm{R} 351 \mathrm{sec} 2$ & 1114.33 & 4.51 & 2.38 & 1.90 & 3.63 & 2.26 & 1.61 \\
\hline R316sec1 & 1028.43 & 4.30 & 2.27 & 1.90 & 3.50 & 2.42 & 1.45 \\
\hline R390sec3 & 1174.24 & 4.20 & 2.17 & 1.94 & 3.55 & 2.78 & 1.28 \\
\hline R437sec1 & 1232.46 & 4.12 & 2.10 & 1.96 & 3.23 & 1.99 & 1.62 \\
\hline
\end{tabular}


measure the volume and used the digital balance with accuracy to $0.0001 \mathrm{gm}$ to weigh the samples. They measured the values of $\rho_{\mathrm{ds}}$ of 58 samples. Results are $(2.2-2.7) \times 10^{3} \mathrm{~kg} \mathrm{~m}^{-3}$, with the lowest value at the slip zone. These values are similar to those obtained by Hsu (2007).

At Hole-B, Hirono et al. (2007b) measured not only (a)

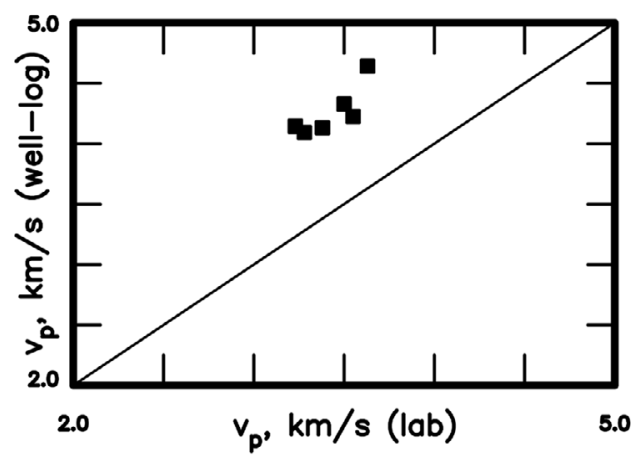

(c)

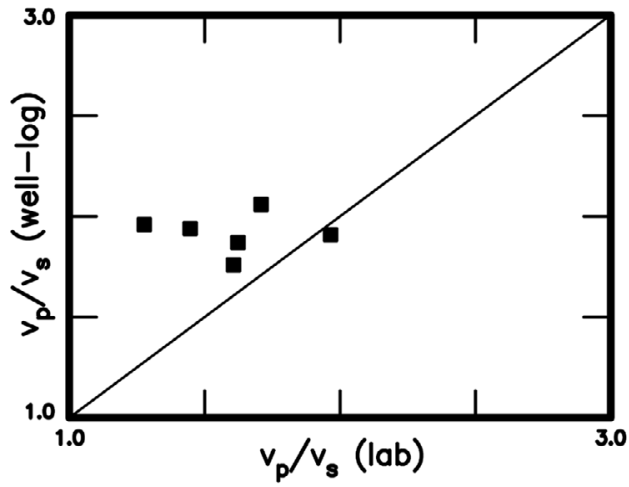

(b)

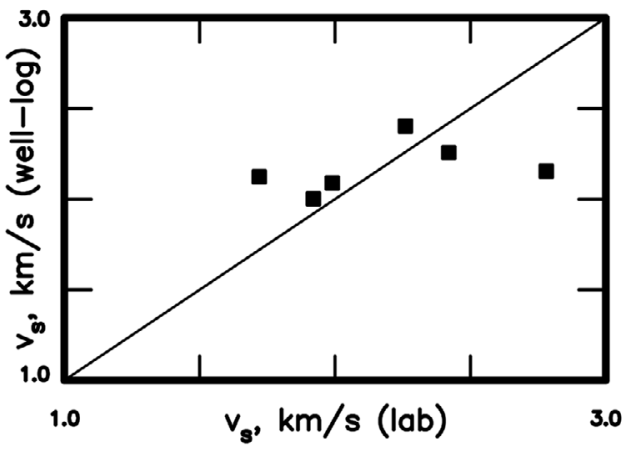

(d)

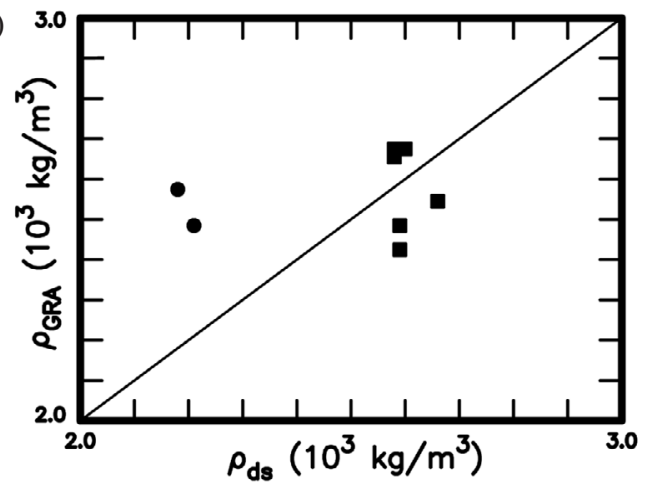

Fig. 5. The plot of well-logged $v_{p}, v_{s}$, and $v_{p} / v_{s}$ versus those measured in laboratory: (a) for $v_{p}$, (b) for $v_{s}$, and (c) for $v_{p} / v_{s}$. In (d), the GRA density, $\rho_{\mathrm{GRA}}$ versus discrete-sample density, $\rho_{\mathrm{ds}}$, is plotted. In each plot, the thin solid line displays the bisection line and the symbols are: a circle for sandstone and a square for silty-shale [revised from Wang et al. (2009)].

Table 4. The values of $\kappa_{\mathrm{o}}$ and $\phi_{\mathrm{o}}$ under the atmospheric pressure, the exponents of the power-law functions of permeability ( $\left.\kappa\right)$ and porosity $(\phi)$, and the values of density $\left(\rho_{\mathrm{ds}}\right.$ and $\left.\rho_{\mathrm{GRA}}\right)$ for 10 rock samples at different depths (z) [from Hsu (2007), Hung et al. (2007), and Dong et al. (2010)].

\begin{tabular}{|c|c|c|c|c|c|c|c|c|}
\hline \multirow{2}{*}{\multicolumn{2}{|c|}{ Sample }} & \multirow{3}{*}{$\begin{array}{c}\mathbf{Z} \\
(\mathbf{m})\end{array}$} & \multirow{3}{*}{$\begin{array}{c}\begin{array}{c}\rho_{\mathrm{ds}} \\
\left(\mathbf{1 0}^{3} \mathbf{k g ~ m}^{-3}\right)\end{array} \\
2.21\end{array}$} & \multirow{3}{*}{$\begin{array}{c}\boldsymbol{\rho}_{\mathrm{GRA}} \\
\left(\mathbf{1 0}^{\mathbf{3}} \mathbf{k g ~ m}^{-3}\right) \\
2.45\end{array}$} & \multicolumn{2}{|c|}{$\mathbf{K}=\mathbf{K}_{\mathrm{o}}\left(\mathbf{p}_{\mathrm{e}} / \mathbf{p}_{\mathrm{a}}\right)^{-\mathrm{n}}$} & \multicolumn{2}{|c|}{$\phi=\phi_{0}\left(p_{e} / p_{a}\right)^{-q}$} \\
\hline & & & & & \multirow{2}{*}{$\frac{\mathbf{K}_{\mathrm{o}}\left(\mathbf{m}^{2}\right)}{1.14 \times 10^{-13}}$} & \multirow{2}{*}{$\begin{array}{c}\mathbf{n} \\
0.112\end{array}$} & \multirow{2}{*}{$\begin{array}{c}\boldsymbol{\phi}_{\mathbf{0}} \\
0.2020\end{array}$} & \multirow{2}{*}{$\begin{array}{c}\mathbf{q} \\
0.037\end{array}$} \\
\hline R261sec2-1 & Sandstone & & & & & & & \\
\hline R261sec2-2 & Sandstone & 915.24 & 2.21 & 2.45 & $2.35 \times 10^{-13}$ & 0.305 & 0.2245 & 0.056 \\
\hline R307sec1 & Sandstone & 1009.62 & 2.18 & 2.54 & $1.37 \times 10^{-13}$ & 0.143 & 0.2075 & 0.040 \\
\hline R255sec2-1 & Silty-shale & 902.68 & 2.59 & 2.45 & $4.91 \times 10^{-17}$ & 0.817 & & \\
\hline R255sec2-2 & Silty-shale & 902.68 & 2.59 & 2.45 & $8.05 \times 10^{-16}$ & 1.357 & 0.1127 & 0.033 \\
\hline R287sec1 & Silty-shale & 972.42 & 2.58 & 2.62 & $6.58 \times 10^{-15}$ & 1.594 & 0.1251 & 0.036 \\
\hline $\mathrm{R} 351 \mathrm{sec} 2$ & Silty-shale & 1114.33 & 2.59 & 2.39 & $2.00 \times 10^{-17}$ & 0.830 & 0.1023 & 0.032 \\
\hline R316sec1 & Silty-shale & 1028.43 & 2.60 & 2.64 & & & 0.1079 & 0.046 \\
\hline R390sec3 & Silty-shale & 1174.24 & 2.66 & 2.51 & $4.08 \times 10^{-13}$ & 1.732 & 0.1272 & 0.036 \\
\hline $\mathrm{R} 437 \mathrm{sec} 1$ & Shale & 1232.46 & 2.58 & 2.64 & $2.70 \times 10^{-18}$ & 0.554 & 0.1476 & 0.014 \\
\hline
\end{tabular}


the values of $\rho_{\mathrm{GRA}}$ in the depth range of $948.42-1352.60 \mathrm{~m}$ using the GRA method, with high accuracy of less than $10 \mathrm{~kg} \mathrm{~m}^{-3}$, but also those of $\rho_{\mathrm{ds}}$ on numerous discrete rock samples. From a comparison between $\rho_{\mathrm{GRA}}$ and $\rho_{\mathrm{ds}}$, they found that the data points of $\rho_{\mathrm{GRA}}$ versus $\rho_{\mathrm{ds}}$ are scattering and $\rho_{\mathrm{GRA}}$ is generally $100 \mathrm{~kg} \mathrm{~m}^{-3}$ higher than $\rho_{\mathrm{ds}}$. Obviously, $\rho_{\mathrm{ds}}$ is more accurate than $\rho_{\mathrm{GRA}}$. The measured values of $\rho_{\mathrm{ds}}$ are: $(2.4-2.7) \times 10^{3}$ and $(2.0-2.4) \times 10^{3} \mathrm{~kg} \mathrm{~m}^{-3}$, respectively, outside and inside the BGZ at the FZB1136; $(2.4-2.7) \times 10^{3}$ and $(2.5-2.7) \times 10^{3} \mathrm{~kg} \mathrm{~m}^{-3}$, respectively, outside and inside the BGZ at the FZB1 194; $(2.1-2.7) \times 10^{3}$ and $(2.2-2.5) \times$ $10^{3} \mathrm{~kg} \mathrm{~m}^{-3}$, respectively, outside and inside the $\mathrm{BGZ}$ at the FZB1143. The results at Holes A and B presented show that the density is not clearly dependent upon the depth.

Essentially, the density values of rocks measured using different methodologies are different. Hung et al. (2007) applied the Triple-detector Lithological Density Log (TDL) to measure the in-situ formation density (containing pore fluids) with a vertical resolution of $5 \mathrm{~cm}$ and within the error of $0.01 \mathrm{~g} \mathrm{~cm}^{-3}$. The density value has been corrected with borehole size (caliper) and mud cake. The photoelectrical factor was also considered to differentiate if an abnormal density value is caused by mud infiltration or minerals inside the formation. Hsu (2007) measured the density value from the weight and volume of dry core samples. Hirono et al. (2007b) applied a similar methodology in well loggings as Hung et al. (2007) except that their samples have no mud and are essentially dry. So, the three types of measurements are different either in methodology or environmental condition. Thereby, the resolution and the value will be different in the three methods.

\subsection{Hydraulic Parameters}

The presence of fluids (mainly water) in rocks can weaken the strength of rocks. Chen et al. (2005) observed $\sim 32 \%$ reduction in the strength of the saturated samples of TCDP cores relative to the corresponding dry samples. Water content is a basic indication presenting the existence of fluids. The flow of fluids in and mechanical properties of rocks are controlled by the effective pressure, $\mathrm{p}_{\mathrm{e}}$, and two parameters, i.e., porosity $(\phi)$ and permeability (к). The effective pressure, $p_{e}$, is equal to $p_{c}-p_{w}$ where $p_{c}$ and $p_{w}$ are, respectively, the confining and pore fluid pressures. Since $\phi$ and $\mathrm{k}$ are dependent on $\mathrm{p}_{\mathrm{e}}$, they are usually measured in a laboratory at different values of $\mathrm{p}_{\mathrm{e}}$. Hydraulic diffusivity, $\mathrm{D}_{\mathrm{h}}$ (in the unit of $\mathrm{m}^{2} \mathrm{~s}^{-1}$ ), is the main factor in controlling fluid pressure and thus affecting effective normal stress, which influences earthquake rupture, during faulting. Assuming a quasi-permanent radial flow inside an aquifer tapped by the leakage of fluids in the casing, the flow through the leak is proportional to the transmissivity $\mathrm{T}_{\mathrm{s}}$ (in the unit of $\mathrm{m}^{2} \mathrm{~s}^{-1}$ ) of the surrounding formation. $T_{s}$ relates to $D_{h}$ in the following equation: $T_{s}=D_{h} \times S$ where $S$ is the storativity which is a dimensionless parameter. $\mathrm{T}_{\mathrm{s}}$ is positively proportional to $\mathrm{K}$. Meanwhile, some other authors measured the specific storage, $\mathrm{S}_{\mathrm{s}}$, whose unit is $\mathrm{Pa}^{-1}$.

\subsubsection{Shallow Holes}

For the shallow holes, the main results measured by several authors (Otsuki et al. 2001; Huang et al. 2002; Tanaka et al. 2002; and Tanikawa et al. 2004) are: (1) at the northern borehole: $\mathrm{K}=10^{-16}-10^{-19} \mathrm{~m}^{2}$ for fault gouge at effective pressures up to $100 \mathrm{MPa}$ and a water content up to $45 \mathrm{vol} \%$; and (2) at the southern one: $\mathrm{K}=10^{-14}-10^{-17} \mathrm{~m}^{2}$ for the matrix of conglomerates and foliated cataclasites at effective pressures up to $100 \mathrm{MPa}$.

\subsubsection{Deep Holes}

At Hole-A, Hung et al. (2007) and Yeh et al. (2007) only quantitatively denoted the water content by using one of the following words: "high", "medium", "low", "few", and "no". At Hole-B, Matsubayashi et al. (2005) measured the water content in the depth ranges from 1142 to $1170 \mathrm{~m}$ and from 1200 to $1235 \mathrm{~m}$. Their measured values are (15 - 26)\%. Lin et al. (2008) applied the time domain reflectometry (TDR) technique, with an error of $\pm 1 \%$, to measure the volumetric water content which is defined as the pore-water volume divided by the total volume of a rock sample at Hole-B. The volumetric water content has a good correlation with the lithology. The measured values are between $2 \%$ and $30 \%$. The volumetric water content shows an abnormal peak in the three fault zones, with the maximum value in the FZB1136 where the volumetric water content is $30 \%$ in the black and gray gouge zones and $20 \%$ in the breccia zone. The maximum volumetric water contents in the FZB1194 and FZB1243 are almost the same and both lower by $5 \%$ than that in the FZB1136.

From a pumping test done between Hole-A and HoleB over three months started from 18 November 2005 about 6 years after the earthquake, Doan et al. (2006) measured the in-situ values of related parameters along the fault zone between the two holes. They obtained $D_{h}=(7 \pm 1) \times$ $10^{-5} \mathrm{~m}^{2} \mathrm{~s}^{-1}, \mathrm{~S}=10^{-7}-10^{-5}$, and $\mathrm{T}_{\mathrm{s}}=10^{-11}-10^{-9} \mathrm{~m}^{2} \mathrm{~s}^{-1}$ from the temporal variation in water level. From the values of $T_{s}$, they reported $\mathrm{K}=10^{-18}-10^{-16} \mathrm{~m}^{2}$ for the fault rocks between the two holes.

For core samples from the fault slip zone, Locker et al. (2005) obtained $\mathrm{K}=(0.4-7) \times 10^{-20} \mathrm{~m}^{2}$, with the lowest value near the axis of the FZA1111, at an effective confining pressure of $15.5 \mathrm{MPa}$. They also measured the value of $\mathrm{S}_{\mathrm{s}}\left[=(1.3-7) \times 10^{-11} \mathrm{~Pa}^{-1}\right]$ at $15.5 \mathrm{MPa}$. Tanikawa et al. (2005) measured $\mathrm{K}$ for the fault gouge: $\mathrm{K}=10^{-15}-10^{-17} \mathrm{~m}^{2}$ for the Chelungpu fault gouge and $\mathrm{K}=10^{-17}-10^{-19} \mathrm{~m}^{2}$ for the Shuangtung fault. They also measured $\mathrm{S}_{\mathrm{s}}=10^{-9}-10^{-10} \mathrm{~Pa}^{-1}$. $\mathrm{Lu}$ et al. (2005) measured the values of $\phi$ of host rocks in 
the depth range $450-1300 \mathrm{~m}$ at different uniaxial compressive strengths, $\mathrm{p}_{\mathrm{s}}$. Results are $2 \%$ at $\mathrm{p}_{\mathrm{s}}=67-73 \mathrm{MPa}, 6 \%$ at $\mathrm{p}_{\mathrm{s}}=61-65 \mathrm{MPa}$, and $15 \%$ at $\mathrm{p}_{\mathrm{s}}=8-11 \mathrm{MPa}$. Takahasi et al. (2005) measured the values of $\mathrm{K}$ for 18 core samples obtained in the depth range $482-1316 \mathrm{~m}$ under $\mathrm{p}_{\mathrm{e}}=10$ $30 \mathrm{MPa}$. The measured values of $\mathrm{K}$ are $10^{-13} \mathrm{~m}^{2}$ for clean sandstones and $10^{-17} \mathrm{~m}^{2}$ for silty sandstones under $\mathrm{p}_{\mathrm{e}}=$ $25 \mathrm{MPa}$. Chen et al. (2005) measured $\mathrm{k}$ for the bioturbated sandstone and shaly siltstone samples. They found that for the bioturbated sandstone samples at $\mathrm{z}=\sim 588 \mathrm{~m}, \mathrm{~K}$ is on the order of $10^{-14} \mathrm{~m}^{2}$ at $\mathrm{p}_{\mathrm{e}}=5-20 \mathrm{MPa}$ and $\mathrm{k}$ decreases and increases with increasing $\mathrm{p}_{\mathrm{e}}$ before and after brittle faulting, respectively. On the other hand, for the shaly siltstone samples at $\sim 837 \mathrm{~m} \mathrm{~K}=10^{-19}-10^{-18} \mathrm{~m}^{2}$ under $\mathrm{p}_{\mathrm{e}}=5$ $40 \mathrm{MPa}$. They also measured the values of $\phi:(15-18) \%$ for bioturbated sandstone at $\mathrm{z}=\sim 588 \mathrm{~m}$ and $(4-5) \%$ for shaly siltstone of host rocks at $\mathrm{z}=\sim 837 \mathrm{~m}$. Sone et al. (2005) measured $\mathrm{K}$ for fault rock samples at $\mathrm{z}=1153 \mathrm{~m}$ under $\mathrm{p}_{\mathrm{e}}=1$ $140 \mathrm{MPa}$. The measured values are between $10^{-14}-10^{-18} \mathrm{~m}^{2}$. Tanaka et al. (2007) measured the values of $\phi$ for 58 samples in the depth range $1000-1300 \mathrm{~m}$. Results are $\phi=(2.5$ - 3.1)\%. Oku et al. (2007) measured $\phi$ for the rock samples at $\mathrm{z}=889-892.2 \mathrm{~m}$. The average $\phi$ is $(6.9 \pm 0.8) \%$.

Dong et al. (2010) used an integrated permeability/porosity measurement system (called YOYK2) to measure the porosity and permeability of ten discrete core samples in the depth range $900-1235 \mathrm{~m}$ at Hole-A under $\mathrm{p}_{\mathrm{e}}=3-120 \mathrm{MPa}$. The measured values are $\phi=(15-19) \%$ and $\mathrm{K}=10^{-13}$ $10^{-14} \mathrm{~m}^{2}$ for sandstones and $\phi=(8-14) \%$ and $\mathrm{K}=10^{-16}$ $10^{-19} \mathrm{~m}^{2}$ for silty-shale. Dong et al. (2010) found that the power-law function is better than the exponential-law function to describe the dependence of the two parameters on confining pressure. The power-law function is $\mathrm{K}=\mathrm{K}_{\mathrm{o}}\left(\mathrm{p}_{\mathrm{e}} / \mathrm{p}_{\mathrm{a}}\right)^{-\mathrm{n}}$ for permeability and $\phi=\phi_{0}\left(\mathrm{p}_{\mathrm{e}} / \mathrm{p}_{\mathrm{a}}\right)^{-\mathrm{q}}$ for porosity. In the two expressions, $\mathrm{K}_{\mathrm{o}}$ and $\phi_{\mathrm{o}}$ are the values under an atmospheric pressure, $\mathrm{p}_{\mathrm{a}}(\approx 0.1 \mathrm{MPa})$, and $\mathrm{n}$ and $\mathrm{q}$ are the exponents. The values of $\mathrm{K}_{\mathrm{o}}, \phi_{\mathrm{o}}, \mathrm{n}$, and $\mathrm{q}$ for ten samples obtained at different depths are shown in Table 4. Among the ten samples, three for sandstones, seven for silty-shale. The permeability of sample R316sec 1 at $\mathrm{z}=1028.43 \mathrm{~m}$ and the porosity of sample R255sec2-2 at $\mathrm{z}=902.68 \mathrm{~m}$ are not measured.

On the basis of the power-law functions inferred by Dong et al. (2010), Wang et al. (2009) calculated the values of $\phi$ and $\mathrm{K}$ at various depths from $\mathrm{p}_{\mathrm{e}}$ which changes from $0.3 \mathrm{MPa}$ to an upper bound. This upper bound is taken to be $\rho g z$ where $g$ is the gravity acceleration and $\mathrm{z}$ is the depth at which the sample was located. The average density $(=2.47$ $\times 10^{3} \mathrm{~kg} \mathrm{~m}^{-3}$ ) for all samples was used by Wang et al. (2009) to evaluate the upper bound confining pressure. Since the confining pressure $\mathrm{p}_{\mathrm{c}}$ is the lithostatic pressure at the drilled site, $p_{c}=\rho g z$ where $\rho$, is the density of rocks. The pore fluid pressure is $p_{w}=\rho_{w} g z$, where $\rho_{w}$ is the density of pore fluids, and can be written as $\gamma \rho g z$, where $\gamma$ is the pore-fluid factor (cf. Sibson 1992). At shallow depths, where the fluid gradient is hydrostatic, $\gamma$ is the ratio of fluid to rock density, typically $\sim 0.4$. At depths, where the fluid pressure may become suprahydrostatic, $\gamma$ is larger than 0.4 . The effective pressure can be re-written as $p_{e}=(1-\gamma) \rho g z$. It is significant to study the values of $\phi$ and $\mathrm{K}$ at the hydrostatic state with $\mathrm{p}_{\mathrm{w}}=0.4 \mathrm{p}_{\mathrm{c}}$ and thus $\mathrm{p}_{\mathrm{e}}=0.6 \mathrm{p}_{\mathrm{c}}=0.6 \rho \mathrm{gh}$ due to $\gamma=0.4$.

In Fig. 6, for a certain rock sample the calculated values of $\phi$ and $\mathrm{K}$ in the confining pressure range in use are displayed by a horizontal line segment with short line segments at two ends. The values of the two parameters at the hydrostatic state are denoted by a solid symbol: a circle for sandstone and a square for silty-shale. Also plotted in Fig. 6 are the values of $\phi$ and $\mathrm{k}$ obtained by others. In Fig. 6a, the rectangle with number ' 4 ' displays the range of measured values of $\phi$ in the depth range $1000-1300 \mathrm{~m}$ from Tanaka et al. (2007). In Fig. 6b, an open circle denotes the value of $\mathrm{K}$ for bioturbated sandstone from Chen et al. (2005) and a rectangle with number ' 1 ' displays the range of measured values of $\mathrm{K}$ in the depth range $0-455.35 \mathrm{~m}$ from Tanikawa et al. (2004).

The values of $\phi$ well-logged by Tanaka et al. (2007) distribute in a large range from 0.06 to 0.42 . This is due to the abnormally high values of $\phi$ in the fracture zones. Figure 6 shows that $\phi$ and $\mathrm{K}$ are in general higher for sandstone than for silty-shale and shale siltstone. Figure 6a shows that for silty-shale and shaly siltstone, $\phi$ slightly increases with depth, while for sandstone $\phi$ is almost a constant. A comparison between Figs. $6 \mathrm{a}$ and $\mathrm{b}$ shows that the depth variation for silty-shale is higher for permeability than for porosity.

From the laboratory results for 18 samples from 482 to $1316 \mathrm{~m}$ at Hole-A, Takahashi et al. (2005) observed that $\mathrm{K}$ decreases logarithmically with increasing $p_{e}$ when $p_{e}$ is from 10 to $30 \mathrm{MPa}$. However, they took all data into account, ignoring the behavior of individual rock types. Manning and Ingebritsen (1999) proposed a quasi-exponential decay of permeability with depth in the form: $\log (\mathrm{K})=-14.0-3.2 \times$ $\log (\mathrm{z})$. However, this equation which is displayed by a solid line in Fig. $6 \mathrm{~b}$ cannot interpret the observations. Wang et al. (2009) used the two equations: $\log (\mathrm{K})=-13.0-3.2 \times \log (\mathrm{z})$ and $\log (\mathrm{K})=-18.0-3.2 \times \log (\mathrm{z})$ to describe the data points calculated from the power-law functions inferred by Dong et al. (2010). The two equations are shown by dashed and dashed-dotted lines, respectively, in Fig. 6b. The dashed line could somewhat describe the data points for sandstone, and the dashed-dotted line seems able to describe the data points for silty-shale and shaly siltstone. From experimental results, Lockner et al. (2007) proposed $\log (\mathrm{K}) \sim \mathrm{pe}^{-0.074}$ (6.5 $\left.\mathrm{MPa}<\mathrm{p}_{\mathrm{e}}<16.0 \mathrm{MPa}\right)$. As mentioned in Lockner et al. (2007), there is no monotonously increasing or decreasing depth-function of $\log (\mathrm{K})$.

Hirono et al. (2007b) measured, with accuracy of $0.1 \%$, the porosity inside the FZB1136 in the depth range 1134 $1137 \mathrm{~m}$ at Hole-B. Their results are $>30 \%$ and $\sim 10 \%$ inside and outside this zone, respectively. 

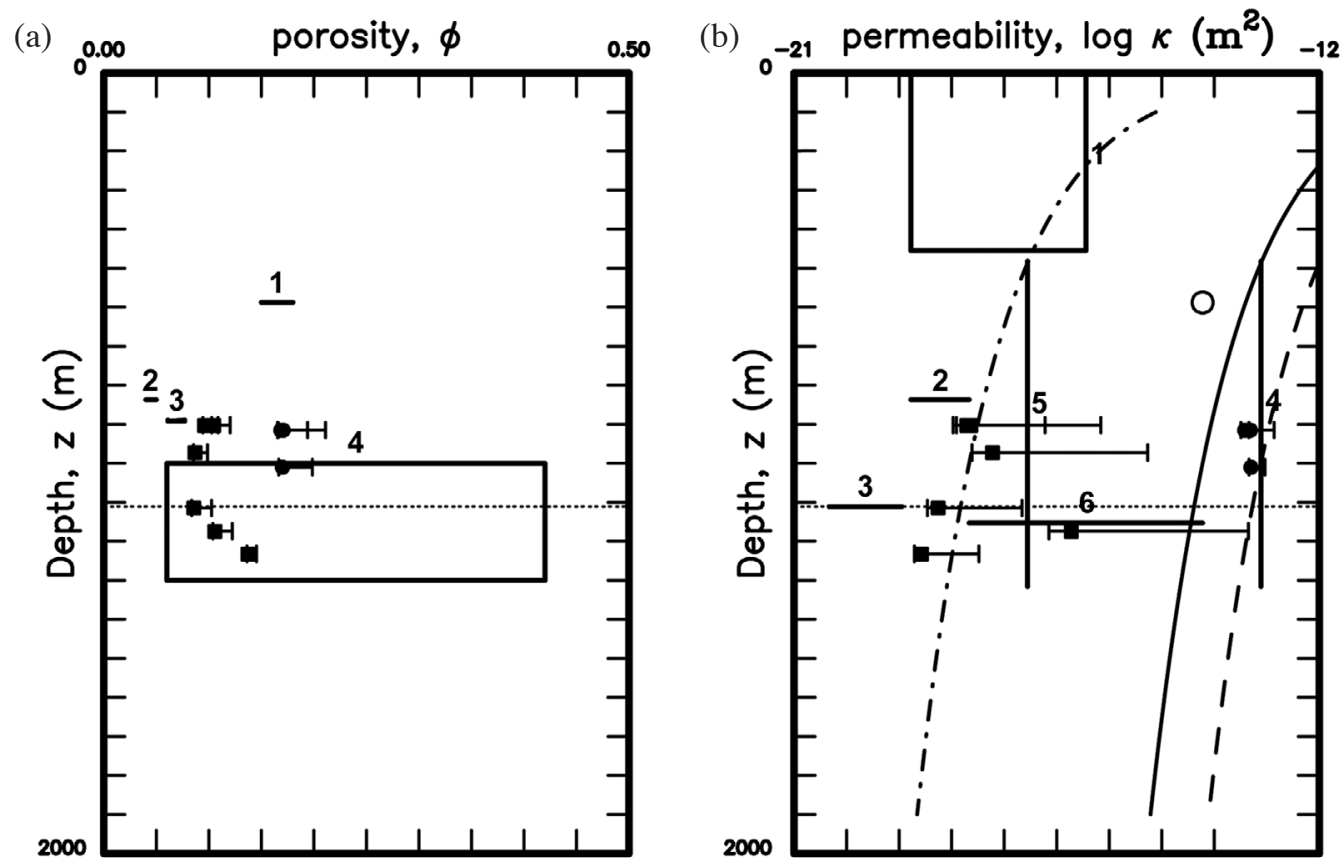

Fig. 6. Figure shows (a) the plot of porosity $(\phi)$ versus depth and (b) the permeability (к) versus depth. The horizontal thin dotted lines denote the PSZ. The horizontal line segment with short line segments at two ends displays the values of related parameter in the individual confining pressure range calculated from the power-law functions inferred by Dong et al. (2010) and a solid symbol (a circle for sandstone and a square for silty-shale) denotes the value at the hydrostatic state. The horizontal and vertical line segments with numbers represent the ranges of measured values: (1) in Fig. 6a: ' 1 ' for bioturbated sandstone from Chen et al. (2005), '2' for shaly siltstone from Chen et al. (2005), and ' 3 ' from Oku et al. (2007); (2) in Fig. 6b: ' 2 ' for shaly siltstone from Chen et al. (2005); ' 3 ' from Lockner et al. (2005), '4' for clean sandstone from Takahashi et al. (2005), '5' for silty sandstone from Takahashi et al. (2005), and '6' from Sone et al. (2005). In Fig. 6a, a rectangle with the number '4' displays the range of measured values of $\phi$ in the depth range 1000 - $1300 \mathrm{~m}$ from Takahashi et al. (2005). In (b), an open circle denotes the value of $\mathrm{k}$ for bioturbated sandstone from Chen et al. (2005); a rectangle with the number ' 1 ' displays the range of measured values of $\mathrm{K}$ in the depth range $0-455.35 \mathrm{~m}$ from Tanikawa et al. (2004); and the solid, dashed, and dashed-dotted lines display three relationships of $\log (\mathrm{k})$ versus $\log (\mathrm{z})$ as explained in the text.

\subsection{Thermal Parameters}

The main thermal parameters include the temperature $\left(\mathrm{T}\right.$ in $\left.{ }^{\circ} \mathrm{C}\right)$, temperature rise $\left(\Delta \mathrm{T}\right.$ in $\left.{ }^{\circ} \mathrm{C}\right)$, thermal gradient (in ${ }^{\circ} \mathrm{C} \mathrm{km}^{-1}$ ), thermal conductivity ( $\mathrm{K}$ in $\mathrm{J} \mathrm{kg}^{-1} \mathrm{~s}^{-1}{ }^{\circ} \mathrm{C}^{-1}$ ), thermal diffusivity $\left(\alpha\right.$ in $\left.\mathrm{m}^{2} \mathrm{~s}^{-1}\right)$, and specific heat $\left(\mathrm{C}_{\mathrm{v}}\right.$ in $\left.\mathrm{J} \mathrm{kg}^{-1}{ }^{\circ} \mathrm{C}^{-1}\right)$. The specific heat, $\mathrm{C}_{\mathrm{v}}$, is defined to be $\mathrm{k} / \rho \alpha$.

\subsubsection{Shallow Holes}

In the two shallow holes, Mori (2004) measured $\Delta \mathrm{T}$ about 1.4 years after the earthquake. The peak values of $\Delta \mathrm{T}$ on the fault plane are 0.5 and $0.1^{\circ} \mathrm{C}$, respectively, in the southern and northern holes. $\Delta \mathrm{T}$ decreases with increasing distance from the fault plane as described by a 1-D conduction equation (Officer 1974). According to the spatial distribution of $\Delta \mathrm{T}$, Mori (2004) inferred the values $\mathrm{K}$ and $\alpha$. His results are $\mathrm{K}=1.14 \times 10^{3} \mathrm{~J} \mathrm{~kg}^{-1} \mathrm{~s}^{-1}{ }^{\circ} \mathrm{C}^{-1}$ and $\alpha=2.0 \times 10^{-6} \mathrm{~m}^{2} \mathrm{~s}^{-1}$ for the northern hole and $\mathrm{K}=1.14 \times$ $10^{3} \mathrm{~J} \mathrm{~kg} \mathrm{k}^{-1} \mathrm{~s}^{-1}{ }^{\circ} \mathrm{C}^{-1}$ and $\alpha=5.0 \times 10^{-7} \mathrm{~m}^{2} \mathrm{~s}^{-1}$ for the southern hole. Tanaka et al. (2006) used the HOT DISK system to measure $\alpha$ from 57 data obtained from the materials at different depths around the slip zone and took the average, i.e.,
$(1.47 \pm 0.04) \times 10^{-6} \mathrm{~m}^{2} \mathrm{~s}^{-1}$, to be the representative thermal diffusivity of the slip zone, because they assumed that the thickness of the slip zone is narrow. They evaluated the value of $\mathrm{c}$ from the spatial distribution of $\Delta \mathrm{T}$ on the basis of the values of $\alpha$ and $\rho$. The average of $\mathrm{C}_{\mathrm{v}}$ is $326 \pm 42 \mathrm{~J} \mathrm{~kg}^{-1}{ }^{\circ} \mathrm{C}^{-1}$. Meanwhile, the thermal gradient measured from the spatial distribution of $\mathrm{T}$ by them is $5-6^{\circ} \mathrm{C} \mathrm{km}^{-1}$.

\subsubsection{Deep Holes}

Kano et al. (2006) conducted temperature measurements, with a resolution of $0.003{ }^{\circ} \mathrm{C}$, at Hole-A, in September 2005 six years after the earthquake. They obtained a spatial distribution of $\Delta \mathrm{T}$ between -60 and $+60 \mathrm{~m}$ with respect to the fault plane. The maximum value of $\Delta \mathrm{T}$ and the ambient temperature on the fault plane are 0.06 and $46.5^{\circ} \mathrm{C}$, respectively. Kano et al. (2006) inferred the values of $\mathrm{c}$ and $\alpha$ from the spatial distribution of $\Delta \mathrm{T}$. The optimum values are $\mathrm{C}_{\mathrm{v}}=1.7 \times 10^{3} \mathrm{~J} \mathrm{~kg}^{-1}{ }^{\circ} \mathrm{C}^{-1}$ and $\alpha=0.34 \times 10^{-6} \mathrm{~m}^{2} \mathrm{~s}^{-1}$. They also obtained $\mathrm{K}=1.3 \mathrm{~J} \mathrm{~kg}^{-1} \mathrm{~s}^{-1}{ }^{\circ} \mathrm{C}^{-1}$. From the core samples of Hole-A, Tanaka et al. (2007) used the Transient Plane Source (TPS) technique to measure $\mathrm{k}$ and $\alpha$ of host and fault-zone rocks. The measurement error is $<3 \%$ for $\mathrm{K}$ 
and $<5 \%$ for $\alpha$. Results are $\mathrm{K}=(1.0-3.0) \mathrm{J} \mathrm{kg}^{-1} \mathrm{~s}^{-1}{ }^{\circ} \mathrm{C}^{-1}$, with the lowest value around $1.0 \mathrm{~J} \mathrm{~kg}^{-1} \mathrm{~s}^{-1}{ }^{\circ} \mathrm{C}^{-1}$ at the slip zones, and $\alpha=(0.8-2.0) \times 10^{-6} \mathrm{~m}^{2} \mathrm{~s}^{-1}$. They also calculated the value of $C_{v}$ from those of $\kappa, \rho$, and $\alpha$. Results are $(0.3-1.0) \times$ $10^{3} \mathrm{~J} \mathrm{~kg} \mathrm{k}^{-1}{ }^{\circ} \mathrm{C}^{-1}$, with the smallest value of $0.3 \times 10^{3} \mathrm{~J} \mathrm{~kg}^{-1}{ }^{\circ} \mathrm{C}^{-1}$ in the slip zone. From the measurements of transient mud temperatures $\left( \pm 10^{-3}{ }^{\circ} \mathrm{C}\right)$ in the depth ranges $500-1275$ and $1275-1842 \mathrm{~m}$, Hung et al. (2007) found that the thermal gradient was $9{ }^{\circ} \mathrm{C} \mathrm{km}^{-1}$ in the former and $7{ }^{\circ} \mathrm{C} \mathrm{km}^{-1}$ in the latter. Matsubayashi et al. (2005) measured the values of $\mathrm{K}$ for unfractured rocks in two depth ranges from 1142 to $1170 \mathrm{~m}$ and from 1200 to $1235 \mathrm{~m}$ at Hole-B. The measured values are $(2.2-3.7) \times 10^{3} \mathrm{~J} \mathrm{~kg}^{-1} \mathrm{~s}^{-1}{ }^{\circ} \mathrm{C}^{-1}$.

\subsection{Electric and Magnetic Parameters}

Hung et al. (2007) measured the electric resistivity in the depth range $500-1750 \mathrm{~m}$ at Hole-A. The values are 10 - $30 \mathrm{ohm}-\mathrm{m}$, and there is no clear correlation between electric resistivity and depth. Overall, the electric resistivity is higher for sandstone than for shale. The electric resistivity is lower inside than outside the fault zone. The FZA1111 has the lowest electric resistivity than other fault zones.

Magnetic susceptibility represents the degree to which materials can be magnetized by an external magnetic field (H)(cf. Purcell 1968). Let M be the magnetization of the material (the magnetic dipole moment per unit volume). The volume magnetic susceptibility, represented by the symbol $\mathrm{X}_{\mathrm{vol}}$, is defined by the relationship: $\mathrm{M}=\mathrm{X}_{\mathrm{vol}} \mathrm{H}$, where $\mathrm{X}_{\mathrm{vol}}$ is the volume magnetic susceptibility. In SI units, $\mathrm{M}$ and $\mathrm{H}$ are both measured in amperes per meter, and thus $\mathrm{X}_{\mathrm{vol}}$ is dimensionless. There are two other measures of susceptibility: the mass magnetic susceptibility $\left(X_{\text {mass }}\right)$, measured in $\mathrm{m}^{3} \mathrm{~kg}^{-1}$ (in $\mathrm{SI})$, and the molar magnetic susceptibility $\left(\mathrm{X}_{\mathrm{mol}}\right)$, measured in $\mathrm{m}^{3} \mathrm{~mol}^{-1}$ (in SI). Let $\rho$ and $\mathrm{m}$ be, respectively, the density in $\mathrm{kg} \mathrm{m}^{-3}$ and the molar mass in $\mathrm{kg} \mathrm{mol}^{-1}$. The conversion formulae between any two quantities are: $X_{\text {mass }}=X_{v o l} / \rho$ and $\mathrm{X}_{\mathrm{mol}}=\mathrm{mX}_{\text {mass }}=\mathrm{mX}_{\mathrm{vol}} / \rho$.

Hirono et al. (2006a, 2007b) measured (volume) magnetic susceptibility at Hole-B using the Bartington loop sensor (MS2C) with a 10-cm loop diameter. Measured values are in the range of $(28-60) \times 10^{-5} \mathrm{SI}$, with higher peak values within the BGZ: $(30-60) \times 10^{-5}$ and $(50-80) \times 10^{-5} \mathrm{SI}$ outside and inside the BGZ at FZB1136; $(28-52) \times 10^{-5}$ and $50 \times 10^{-5}$ SI outside and inside the BGZ at FZB1194; $(27-54) \times 10^{-5}$ and $(40-55) \times 10^{-5}$ SI outside and inside the BGZ at FZB1143. They also measured the values of magnetic susceptibility for three formations: $(20-80) \times 10^{-5} \mathrm{SI}$ for the Cholan Formation, $(30-150) \times 10^{-5}$ SI for the Chinshui Shale, and $(30-200) \times 10^{-5}$ SI for the Kueichulin Formation. They assumed that temperature rise of more than $450^{\circ} \mathrm{C}$ due to frictional heating could be responsible for high magnetic susceptibility in the BGZ. Tanikawa et al. (2008) measured bulk magnetic susceptibility of the crushed silt from the $1134 \mathrm{~m}$ of Hole-B after heating test in the temperature range from room temperature $\left(\right.$ denoted by $0^{\circ} \mathrm{C}$ in the figures of their papers) to $900^{\circ} \mathrm{C}$. They found that bulk magnetic susceptibility increases with temperature and the values are in the range of $(10-500) \times 10^{-8} \mathrm{~m}^{3} \mathrm{~kg}^{-1}$. From the HVR tests using the high-speed rotary-shear testing apparatus made by Shimamoto and Tsutsumi (1994), they also observed that magnetic susceptibility is increased after the HVR testing and proportional to the normal stress and slip displacement.

\section{SOME CORRELATIONS BETWEEN PHYSICAL PARAMETERS}

Wang et al. (2009) studied the correlations between physical parameters measured from well-logging and/or laboratory experiments. The details can be found in their article, and only the results are given below.

\subsection{Correlation between $v_{s}$ and $v_{p}$}

From well-logged data, Wang et al. (2009) correlated $\mathrm{v}_{\mathrm{s}}$ to $\mathrm{v}_{\mathrm{p}}$ in the following form:

$\mathrm{v}_{\mathrm{s}}=(-0.91 \pm 0.02)+(0.72 \pm 0.01) \mathrm{v}_{\mathrm{p}}$

For dry, perfectly elastic crustal materials, the commonly used formula to relate $\mathrm{v}_{\mathrm{s}}$ to $\mathrm{v}_{\mathrm{p}}$ is: $\mathrm{v}_{\mathrm{s}}=0.58 \mathrm{v}_{\mathrm{p}}$. Compared with Eq. (5), $v_{s}$ cannot be calculated from $v_{p}$ on the basis of the commonly used formula. This might be due to a reason that rocks are porous and wet. Wang et al. (2009) also emphasized that Eq. (5) is different from the Castagna mudrock equation: $\mathrm{v}_{\mathrm{s}}=-1.17+0.86 \mathrm{v}_{\mathrm{p}}($ Castagna et al. 1985) and from the empirical equation: $\mathrm{v}_{\mathrm{s}}=0.7858-1.2344 \mathrm{v}_{\mathrm{p}}+0.7949 \mathrm{v}_{\mathrm{p}}^{2}-$ $0.1238 \mathrm{v}_{\mathrm{p}}^{3}+0.0064 \mathrm{v}_{\mathrm{p}}{ }^{4}$ (Brocher 2005).

\subsection{Correlations between Seismic Velocities and Porosity}

Wang et al. (2009) constructed the relationships between seismic velocities $\left(\mathrm{v}_{\mathrm{p}}\right.$ and $\left.\mathrm{v}_{\mathrm{s}}\right)$ and $\phi$. The linear regression equations are:

$\mathrm{v}_{\mathrm{p}}=(4.49 \pm 0.13)-(2.54 \pm 3.07) \phi$

for the P-waves and

$\mathrm{v}_{\mathrm{s}}=(2.42 \pm 0.09)-(2.31 \pm 1.88) \phi$

for the S-waves. Wang et al. (2009) obtained the porositydependent function of $\mathrm{v}_{\mathrm{p}} / \mathrm{v}_{\mathrm{s}}$ :

$\mathrm{v}_{\mathrm{p}} / \mathrm{v}_{\mathrm{s}}=(4.49-2.54 \phi) /(2.42-2.31 \phi)$ 
The calculations of the averages of $\mathrm{v}_{\mathrm{p}}$ and $\mathrm{v}_{\mathrm{s}}$ as mentioned above are dominated by the velocities of wall rocks, because there are only few logged data in the $12-\mathrm{cm}$ narrow PSZ. The porosity and degree of fractures where fluids could exist is usually smaller in the fault rocks than in the wall rocks. This would make the pore fluid pressure $p_{w}$ be higher in the former than in the latter.

In spite of rock types, seismic velocities remarkably decrease from silty-shale to sandstone. Equations (6) and (7) show that $v_{p}$ and $v_{s}$ both decrease with increasing $\phi$. For 18 rock samples, Kitamura et al. (2005) observed a decrease of seismic velocity from siltstone to sandstone at low pore fluid pressure. From laboratory experiments for different rocks, Castagna et al. (1985) observed a decrease in $v_{p}$ as well as $\mathrm{v}_{\mathrm{s}}$ with increasing $\phi$. They also constructed the relationships between seismic velocities and porosity. Equations (6) and (7) are close to the relationships for elastic silicate obtained by Castagna et al. (1985): $\mathrm{v}_{\mathrm{p}}=5.81-9.42 \phi$ and $\mathrm{v}_{\mathrm{s}}=3.89-7.07 \phi$. Equations (6) and (7) show that a small difference in the decreasing rates of velocity versus porosity for $\mathrm{v}_{\mathrm{p}}$ and $\mathrm{v}_{\mathrm{s}}$. This indicates that a change of porosity can make a similar effect on both $\mathrm{v}_{\mathrm{p}}$ and $\mathrm{v}_{\mathrm{s}}$. It is noted that the standard error of the decreasing rate is higher for $\mathrm{v}_{\mathrm{p}}$ than for $\mathrm{v}_{\mathrm{s}}$. The two equations also lead to that the seismic velocities for dry rocks with $\phi=0$ are $\mathrm{v}_{\mathrm{p}}=4.49 \mathrm{~km} \mathrm{~s}^{-1}$ and $\mathrm{v}_{\mathrm{s}}=2.42 \mathrm{~km} \mathrm{~s}^{-1}$. This gives $\mathrm{v}_{\mathrm{p}} / \mathrm{v}_{\mathrm{s}}=1.85$ when $\phi=0$.

From the values of $\mathrm{v}_{\mathrm{p}}$ and $\mathrm{v}_{\mathrm{s}}$ inside the PSZ as mentioned above, the values of $\phi$ can be calculated from Eqs. (6) and (7). Results are 0.48 from $v_{p}$ and 0.44 from $v_{s}$. The value calculated from $\mathrm{v}_{\mathrm{p}}$ is 0.04 higher than that from $\mathrm{v}_{\mathrm{s}}$. These computed values are higher than the lower bound of $\phi=0.30$ of the fault zone measured by Hirono et al. (2007b). This indicates that the porosity of the fault zone seems unable to be evaluated from the relationships between seismic velocities versus porosity for wall rocks.

Inserting Eq. (6) into Eq. (7), Wang et al. (2009) obtained $\mathrm{v}_{\mathrm{s}}=-1.66+0.91 \mathrm{v}_{\mathrm{p}}$. The dashed-dotted line is somewhat close to the solid line associated with Eq. (6) obtained from all well-logged data. Figure $6 \mathrm{~d}$ demonstrates that $\mathrm{v}_{\mathrm{p}} / \mathrm{v}_{\mathrm{s}}$ slightly increases with $\phi$. The solid line associated with Eq. (8) is able to describe the data points.

\subsection{Correlation between Density and Porosity}

Wang et al. (2009) constructed the correlation between density and porosity. The inferred density-porosity correlation is:

$\rho=(3.22 \pm 0.12)-(5.99 \pm 0.90) \phi$

This equation gives $\rho=3.22(1-1.86 \phi)$, which is different from the simplified correlation: $\rho=\rho_{\mathrm{o}}(1-\phi)$ proposed by Han and Batzle (2004). The effect on $\rho$ from a change of $\phi$ is roughly two times higher from Eq. (9) than from the correlation by Han and Batzle (2004).

\subsection{Correlations between Bulk and Shear Modulus and Porosity}

The bulk modulus and shear modulus of saturated rocks can be written as:

$$
\begin{aligned}
& \mathrm{K}=\rho\left(\mathrm{v}_{\mathrm{p}}^{2}-4 \mathrm{v}_{\mathrm{s}}^{2} / 3\right) \\
& \mu=\rho \mathrm{v}_{\mathrm{s}}^{2}
\end{aligned}
$$

Since $\mathrm{v}_{\mathrm{p}}$ and $\mathrm{v}_{\mathrm{s}}$ are a function of $\phi, \mathrm{K}$, and $\mu$, they are also dependent on $\phi$. Inserting Eqs. (6), (7), and (9) into Eqs. (10) and (11) led to

$$
\begin{aligned}
& \mathrm{K}=40.89\left(1-1.77 \phi+0.81 \phi^{2}+0.10 \phi^{3}\right) \quad \text { (in GPa) } \\
& \mu=19.18\left(1-3.77 \phi+4.46 \phi^{2}-1.69 \phi^{3}\right) \quad \text { (in GPa) }
\end{aligned}
$$

by Wang et al. (2009). Obviously, the effect of the $\phi^{3}$ term is positive for $\mathrm{K}$ and negative for $\mu$, and the magnitude of such an effect is lower on $\mathrm{K}$ than on $\mu$. $\mathrm{K}$ and $\mu$ both decrease monotonously with increasing $\phi$. Equations (12) and (13), respectively, give $K_{o}=40.89 \mathrm{GPa}$ and $\mu_{0}=19.18 \mathrm{GPa}$ at $\phi=0$ for dry rocks. The value of $\mu_{0}$ is about two third of the commonly used value, i.e., $30 \mathrm{GPa}$, for crustal materials.

\section{SUMMARY}

After the $1999 \mathrm{M}_{\mathrm{s}}$ 7.6 Chi-Chi earthquake, several shallow and deep holes penetrating the Chelungpu fault were drilled. The mechanical, thermal, hydraulic, and electric and magnetic parameters measured directly on the discrete core samples or through well-loggings are reviewed in this work. Some concluding remarks are given below:

1. At FZA1111, the dip is $20-30^{\circ}$ towards the SE and the dip direction is $105^{\circ}$. The displacement is about $12 \mathrm{~m}$ inferred from seismograms and $4.24 \mathrm{~m}$ from surface surveys.

2. The grain size is smaller inside than outside the MSZ.

3. The friction coefficient was very low during faulting and not clearly dependent on depth.

4. Although, on the average the density value is smaller inside than outside the black gouge zone, it is not a function of depth.

5. A one-variable polynomial function can describe the depth variations in $\mathrm{v}_{\mathrm{p}}$ and $\mathrm{v}_{\mathrm{s}}$.

6. It is clear that $\mathrm{v}_{\mathrm{s}}$ linearly increases with $\mathrm{v}_{\mathrm{p}}$. However, the inferred relationship of $\mathrm{v}_{\mathrm{s}}$ versus $\mathrm{v}_{\mathrm{p}}$ is different from the equation: $\mathrm{v}_{\mathrm{s}}=0.58 \mathrm{v}_{\mathrm{p}}$ for the perfectly elastic material. 
7. The values of $\phi$ and $\mathrm{k}$ are larger for sandstone than for silty-shale and shaly silt-sandstone.

8. For silty-shale and shaly silt-sandstone, the porosity slightly increases with depth, while for sandstone it is almost constant in the study depth range.

9. A one-variable polynomial function can interpret the depth dependence of permeability. However, such depth functions are different for sandstone and silty-shale.

10. Both $\mathrm{v}_{\mathrm{p}}$ and $\mathrm{v}_{\mathrm{s}}$ linearly decrease with increasing $\phi$. The effects on $v_{p}$ and $v_{s}$ caused by a change of $\phi$ are almost similar. The ratio of $\mathrm{v}_{\mathrm{p}}$ to $\mathrm{v}_{\mathrm{s}}$ slightly increases with $\phi$.

11. Density decreases with increasing porosity.

12. Magnetic susceptibility is abnormally high and electric resistivity is low inside the slip zone.

13. The bulk and shear modulus at the dry condition are 40.89 and $19.18 \mathrm{GPa}$, respectively.

Acknowledgements The author thanks Prof. J. M. Chiu and an anonymous reviewer for their valuable comments to improve this article. The author would like to express his thanks to the working teams for drilling shallow and deep holes. Without their efforts, much significant data could not have been gained. The study was financially supported by Academia Sinica (Taipei) and the National Science Council under Grant No. NSC96-2116-M-001-012-MY3.

\section{REFERENCES}

Boore, D. M. and W. B. Joyner, 1997: Site amplifications for generic rock sites. Bull. Seismol. Soc. Am., 1287, 327-341.

Brocher, T. M., 2005: Empirical relations between elastic wavespeeds and density in the Earth's crust. Bull. Seismol. Soc. Am., 95, 2081-2092, doi: 10.1785/01200500 77. [Link]

Castagna, J. P., M. L. Batzle, and R. L. Eastwood, 1985: Relationships between compressional-wave and shearwave velocities in elastic silicate rocks. Geophysics, 50, 571-581, doi: 10.1190/1.1441933. [Link]

CGS (Central Geological Survey), 1999: Report of Geological Surveys of the 921 Chi-Chi Major Earthquake, Central Geological Survey, Ministry of Economic Affairs, ROC, 315 pp. (in Chinese)

Chen, T. M. N., W. Zhu, T. F. Wong, and S. R. Song, 2005: Hydromechanical behavior of country rock samples from the Taiwan Chelungpu-fault Drilling Project. Eos, Trans., AGU, 86, Fall Meet. Suppl., Abstract, T51A-1324, F1830.

Chester, F. M. and J. S. Chester, 1998: Ultracataclasite structure and friction processes of the Punchbowl fault, San Andreas system, California. Tectonophysics, 295, 199221, doi: 10.1016/S0040-1951(98)00121-8. [Link]

Chester, F. M., J. P. Evans, and R. L. Biegel, 1993: Internal structure and weakening mechanisms of the San
Andreas fault. J. Geophys. Res., 98, 771-786, doi: 10. 1029/92JB01866. [Link]

Doan, M. L., E. E. Brodsky, Y. Kano, and K. F. Ma, 2006: In situ measurement of the hydraulic diffusivity of the active Chelungpu fault, Taiwan. Geophys. Res. Lett., 33, L16317, doi: 10.1029/2006GL026889. [Link]

Dong, J. J., J. Y. Hsu, T. Shimamoto, J. H. Hung, E. C. Yeh, and Y. H. Wu, 2010: Elucidating the relation between confining pressure and fluid flow properties of young sedimentary rocks retrieved from a $2 \mathrm{~km}$ deep holeTCDP Hole-A, preprint.

Han, D. H. and M. L. Batzle, 2004: Gassmann's equation and fluid-saturation effects on seismic velocities. Geophysics, 69, 398-405, doi: 10.1190/1.1707059. [Link]

Hirono, T., W. Lin, E. C. Yeh, W. Soh, Y. Hashimoto, H. Sone, O. Matsubayashi, K. Aoike, H. Ito, M. Kinoshita, M. Murayama, S. R. Song, K. F. Ma, J. H. Hung, C. Y. Wang, and Y. B. Tsai, 2006a: High magnetic susceptibility of fault gouge within Taiwan Chelungpu fault: Nondestructive continuous measurements of physical and chemical properties in fault rocks recovered from Hole B, TCDP. Geophys. Res. Lett., 33, L15303, doi: 10.1029/2006GL026133. [Link]

Hirono, T., M. Ikehara, K. Otsuki, T. Mishima, M. Sakaguchi, W. Soh, M. Omori, W. Lin, E. C. Yeh, W. Tanikawa, and C. Y. Wang, 2006b: Evidence of frictional melting from disk-shaped black material, discovered within the Taiwan Chelungpu fault system. Geophys. Res. Lett., 33, L19311, doi: 10.1029/2006GL027329. [Link]

Hirono, T., T. Yokoyama, Y. Hamada, W. Tanikawa, T. Mishima, M. Ikehara, V. Famin, M. Tanimizu, W. Lin, W. Soh, and S. R. Song, 2007a: A chemical kinetic approach to estimate dynamic shear stress during the 1999 Taiwan Chi-Chi earthquake. Geophys. Res. Lett., 34, L19308, doi: 10.1029/2007GL030743. [Link]

Hirono, T., E. C. Yeh, W. Lin, H. Sone, T. Mishima, W. Soh, Y. Hashimoto, O. Matsubayashi, K. Aoike, H. Ito, M. Kinoshita, M. Murayama, S. R. Song, K. F. Ma, J. H. Hung, C. Y. Wang, Y. B. Tsai, T. Kono, M. Nishimura, S. Moriya, T. Tanaka, T. Fujiki, L. Maeda, H. Muraki, T. Kuramoto, K. Sugiyama, and T. Sugawara, 2007b: Nondestructive continuous physical property measurements of core samples recovered from hole B, Taiwan, Chelungpu-fault Drilling Project. J. Geophys. Res., 112, B07404, doi: 10.1029/2006JB004738. [Link]

Hsu, R. Y., 2007: Stress-dependent fluid flow properties of sedimentary rocks and overpressure generation. Master Thesis, Graduate Inst. Appl. Geol., Natl. Central Univ., 73 pp.

Huang, M. W., J. H. Wang, K. F. Ma, C. Y. Wang, J. H. Hung, and K. L. Wen, 2007: Frequency-dependent site amplifications with $f \geq 0.01 \mathrm{~Hz}$ evaluated from the velocity and density models in Central Taiwan. Bull. Seis- 
mol. Soc. Am., 97, 624-637, doi: 10.1785/0120060139. [Link]

Huang, S. T., J. C. Wu, H. H. Hung, and H. Tanaka, 2002: Studies of sedimentary facies, stratigraphy, and deformation structures of the Chelungpu fault zone on cores from drilled wells in Fengyuan and Nantou, central Taiwan. Terr. Atmos. Ocean. Sci., 13, 253-278.

Hung, J. H., Y. H. Wu, E. C. Yeh, and TCDP Scientific Party, 2007: Subsurface structure, physical properties, and fault zone characteristics in the scientific drill holes of Taiwan Chelungpu-fault Drilling Project. Terr. Atmos. Ocean. Sci., 18, 271-293, doi: 10.3319/ TAO.2007.18.2.271(TCDP). [Link]

Kano, Y., J. Mori, R. Fujio, H. Ito, T. Yanagidani, S. Nakao, and K. F. Ma, 2006: Heat signature on the Chelungpu fault associated with the 1999 Chi-Chi, Taiwan, earthquake. Geophys. Res. Lett., 33, L14306, doi: 10.1029/2006GL026733. [Link]

Kitamura, K., M. Takahashi, K. Masuda, H. Ito, S. R. Song, and C. Y. Wang, 2005: The relationship between porepressure and the elastic-wave velocities of TCDP cores. Eos, Trans., AGU, 86, Fall Meet., Suppl., Abstract T51A-1326, F1833.

Kuo, L. W., S. R. Song, and H. F. Chen, 2005: Characteristics of clay minerals in the fault zone of TCDP and its implications. Eos, Trans., AGU, 86, Fall Meet., Suppl., Abstract T43D-05, F1825.

Kuo, L. W., S. R. Song, E. C. Yeh, and H. F. Chen, 2009: Clay mineral anomalies in the fault zone of the Chelungpu fault, Taiwan, and their implications. Geophys. Res. Lett., 36, L18306, doi: 10.1029/2009GL039269. [Link]

Lin, A. T.-S., S. M. Wang, J. H. Hung, M. S. Wu, and C. S. Liu, 2007: Lithostratigraphy of the Taiwan Chelungpu-fault Drilling Project-A borehole and its neighboring region, central Taiwan. Terr. Atmos. Ocean. Sci., 18, 223-241, doi: 10.3319/TAO.2007.18.2.223(TCDP). [Link]

Lin, W., O. Matsubayashi, E. C. Yeh, T. Hirono, W. Tanikawa, W. Soh, C. Y. Wang, S. R. Song, and M. Murayama, 2008: Profiles of volumetric water content in fault zones retrieved from hole B of the Taiwan Chelungpufault Drilling Project (TCDP). Geophys. Res. Lett., 35, L01305, doi: 10.1029/2007GL032158. [Link]

Lockner, D. A., C. Morrow, and S. R. Song, 2007: Effect of brine composition and concentration on physical properties of clay and shale and strength, velocity and permeability of TCDP Hole A whole core samples, Lecture Notes presented in TCDP Workshop, May 15, 2007, USGS.

Lockner, D. A., C. Morrow, S. R. Song, S. Tembe, and T. F. Wong, 2005: Permeability of whole core samples of Chelungpu fault, Taiwan TCDP scientific drillhole. Eos, Trans., AGU, 86, Fall Meet., Suppl., Abstract
T43D-04, F1825.

Lu, C. Y., J. C. Hu, L. S. Tsai, M. L. Lin, and F. S. Jeng, 2005: Mechanical characteristics of rocks cored from hanging wall of Chelungpu fault. Eos, Trans., AGU, 86, Fall Meet., Suppl., Abstract T51A-1318, F1831.

Ma, K. F., C. T. Lee, Y. B. Tsai, T. C. Shin, and J. Mori, 1999: The Chi-Chi, Taiwan earthquake: Large surface displacements on an inland thrust fault. Eos, Trans., $A G U$, 80, 605-611, doi: 10.1029/99EO00405. [Link]

Ma, K. F., J. Mori, S. J. Lee, and S. B. Yu, 2001: Spatial and temporal distribution of slip for the 1999 Chi-Chi, Taiwan, earthquake. Bull. Seismol. Soc. Am., 91, 10691087, doi: 10.1785/0120000728. [Link]

Ma, K. F., H. Tanaka, S. R., Song, C. Y. Wang, J. H. Hung, Y. B. Tsai, J. Mori, Y. F. Song, E. C. Yeh, W. Soh, H. Sone, L. W. Kuo, and H. Y. Wu, 2006: Slip zone and energetics of a large earthquake from the Taiwan Chelungpu-fault Drilling Project (TCDP). Nature, 444, 473-476, doi: 10.1038/Nature05253. [Link]

Manning, C. E. and S. E. Ingebritsen, 1999: Permeability of the continental crust: Implications of geothermal data and metamorphic systems. Rev. Geophys., 37, 127150, doi: 10.1029/1998RG900002. [Link]

Matsubayashi, O., W. Lin, T. Hirono, S. R. Song, and J. H. Hung, 2005: Characterization of unfractured wall rocks of TCDP Hole-B by combination of thermal property and TDR measurements in laboratory. Eos, Trans., AGU, 86, Fall Meet., Suppl., Abstract T51A1321, F1832.

Mizoguchi, K., M. Takahashi, W. Tanikawa, K. Masuda, S. R. Song, and W. Soh, 2008: Frictional strength of fault gouge in Taiwan Chelungpu fault obtained from TCDP Hole B. Tectonophysics, 460, 198-205, doi: 10.1016/j. tecto.2008.08.009. [Link]

Mori, J., 2004: Energy budget of the 1999 Chichi, Taiwan, earthquake. ABSTRACTS Vol. 1, Joint AOGS 1st Annual Meeting \& 2nd APHW Conference, 2004, Singapore, 41.

Mori, J., H. Ito, and C. Y. Wang, 2002: Chelungpu fault drilling could resolve seismological issues. Eos, Trans., $A G U, \mathbf{8 3}, 255$ pp.

Officer, C. B., 1974: Introduction to Theoretical Geophysics, Berlin, Springer, 385 pp.

Oku, H., B. Haimson, and S. R. Song, 2007: True triaxial strength and deformability of the siltstone overlying the Chelungpu fault (Chi-Chi earthquake), Taiwan. Geophys. Res. Lett., 34, L09306, doi: 10.1029/2007GL 029601. [Link]

Otsuki, K., T. Uzuki, and Y. Koizumi, 2001: Presentation on core analysis, in Proceed. ICDP Workshop on Drilling the Chelungpu Fault, Taiwan, Taipei, 37.

Purcell, E. M., 1968: Electricity and Magnetism, Berkeley Physics Course, Vol. 2, McGraw-Hill Book Co, New York, 459 pp. 
Rice, J. R., 2006: Heating and weakening of faults during earthquake slip. J. Geophys. Res., 111, B05311, doi: 10.1029/2005JB004006. [Link]

Shimamoto, T. and A. Tsutsumi, 1994: A new rotary-shear high-speed frictional testing machine: Its basic design and scope of research. J. Tecton. Res. Group Jpn., 39, 65-78. (in Japanese)

Shin, T. C. and T. L. Teng, 2001: An overview of the 1999 Chi-Chi, Taiwan, earthquake. Bull. Seismol. Soc. Am., 91, 895-913, doi: 10.1785/0120000738. [Link]

Sibson, R. H., 1992: Implications of fault-valve behavior for rupture nucleation and recurrence. Tectonophysics, 211, 283-293, doi: 10.1016/0040-1951(92)90065-E. [Link]

Sibson, R. H., 2003: Thickness of the seismic slip zone. Bull. Seismol. Soc. Am., 93, 1169-1178, doi: 10.1785/01200 20061. [Link]

Slotnick, M. M., 1936: On seismic computations, with applications, II. Geophysics, 1, 299-305, doi: 10.1190/1.14 37111. [Link]

Sone, H., T. Shimamoto, H. Noda, S. R. Song, K. F. Ma, J. H. Hung, and C. Y. Wang, 2005: Frictional properties and permeability of fault rocks from Taiwan Chelungpu-fault Drilling Project and their implications for high-velocity slip weakening. Eos, Trans., AGU, 86, Fall Meet., Suppl., Abstract T43D-36, F1825.

Sone, H., E. C. Yeh, T. Nakaya, J. H. Hung, K. F. Ma, C. Y. Wang, S. R. Song, and T. Shimamoto, 2007: Mesoscopic structural observations of cores from the Chelungpu fault system, Taiwan Chelungpu-fault Drilling Project Hole-A, Taiwan. Terr. Atmos. Ocean. Sci., 18, 359-377, doi: 10.3319/TAO.2007.18.2.359(TCDP). [Link]

Song, S. R., C. Y. Wang, J. H. Hung, and K. F. Ma, 2007a: Preface to the special issue on Taiwan Chelungpu-fault Drilling Project (TCDP): Site characteristics and onsite measurements. Terr. Atmos. Ocean. Sci., 18, I-VI, doi: 10.3319/TAO.2007.18.2.I(TCDP). [Link]

Song, S. R., L. W. Kuo, E. C., Yeh, C. Y. Wang, J. H., Hung, and K. F. Ma, 2007b: Characteristics of the lithology, fault-related rocks and fault zone structures in TCDP Hole-A. Terr. Atmos. Ocean. Sci., 18, 243-269, doi: 10.3319/TAO.2007.18.2.243(TCDP). [Link]

Takahashi, M., K. Kitamura, K. Masuda, H. Ito, S. R. Song, and C. Y. Wang, 2005: Pressurization effect on bulk properties and pore connection of sedimentary rock specimens from TCDP cores. Eos, Trans., AGU, 86, Fall Meet., Suppl., Abstract T51A-1325, F1833.

Tanaka, H., C. Y. Wang, W. M. Chen, A. Sakaguchi, K. Ujiie, and M. Ando, 2002: Initial science report of shallow drilling penetrating into the Chelungpu fault zone, Tai- wan. Terr. Atmos. Ocean. Sci., 13, 227-251.

Tanaka, H., W. M. Chen, C. Y. Wang, K. F. Ma, N. Urata, J. Mori, and M. Ando, 2006: Frictional heat from faulting of the 1999 Chi-Chi, Taiwan, earthquake. Geophys. Res. Lett., 33, L16316, doi: 10.1029/2006GL 026673. [Link]

Tanaka, H., W. M. Chen, K. Kawabata, and N. Urata, 2007: Thermal properties across the Chelungpu fault zone and evaluations of positive thermal anomaly on the slip zones: Are these residuals of heat from faulting? Geophys. Res. Lett., 34, L01309, doi: 10.1029/2006GL 028153. [Link]

Tanikawa, W., H. Noda, K. Mizoguchi, T. Shimamoto, and J. H. Hung, 2004: Frictional and hydraulic properties of the Chelungpu fault zone and their implications for rupture propagation during the 1999 Chi-Chi earthquake. ABSTRACT Vol. 1, Joint AOGS 1st Annual Meeting \& 2nd APHW Conference, July 5-9, Singapore, 43-44.

Tanikawa, W., T. Shimamoto, H. Noda, and H. Sone, 2005: Hydraulic properties of Chelungpu, Shuangtung, and Shuilikeng fault zones and their implication for fault motion during 1999 Chi-Chi earthquake. Eos, Trans., $A G U$, 86, Fall Meet., Suppl., Abstract T43D-08, F1826.

Tanikawa, W., T. Mishima, T. Hirono, W. Soh, and S. R. Song, 2008: High magnetic susceptibility produced by thermal decomposition of core samples from the Chelungpu fault in Taiwan. Earth Planet. Sci. Lett., 272, 372-381, doi: 10.1016/j.epsl.2008.05.002. [Link]

Wang, J. H., J. H. Hung, and J. J. Dong, 2009: Seismic velocities, porosity, and permeability measured at a deep hole penetrating the Chelungpu fault in central Taiwan. J. Asian Earth Sci., 36, 135-145, doi: 10.1016/j. jseaes.2009.01.010. [Link]

Wu, Y. H., E. C., Yeh, J. J., Dong, L. W., Kuo, J. Y., Hsu, and J. H. Hung, 2008: Core-log integration studies in holeA of Taiwan Chelungpu-fault Drilling Project. Geophys. J. Int., 174, 949-965, doi: 10.1111/j.1365-246X. 2008.03841.x. [Link]

Yabe, Y., S. R. Song, and C. Y. Wang, 2008: In-situ stress at the northern portion of the Chelungpu fault, Taiwan, estimated on boring cores recovered from a $2-\mathrm{km}$-depth hole of TCDP. Earth Planets Space, 60, 809-819.

Yeh, E. C., H. Sone, T. Nakaya, K. H. Ian, S. R. Song, J. H. Hung, W. Lin, T. Hirono, C. Y. Wang, K. F. Ma, W. Soh, and M. Kinoshita, 2007: Core description and characteristics of fault zones from HoleA of the Taiwan Chelungpu-fault Drilling Project. Terr. Atmos. Ocean. Sci., 18, 327-358, doi: 10.3319/ TAO.2007.18.2.327(TCDP). [Link] 